\title{
Effects of wheat straw chop length in high-straw dry cow diets on intake, health, and performance of dairy cows across the transition period
}

\author{
C. D. Havekes, ${ }^{1}$ T. F. Duffield, ${ }^{2}{ }^{\oplus}$ A. J. Carpenter, ${ }^{1} \oplus$ and T. J. DeVries ${ }^{1 *}$ (1) \\ ${ }^{1}$ Department of Animal Biosciences, University of Guelph, Guelph, Ontario, N1G 2W1, Canada \\ ${ }^{2}$ Department of Population Medicine, University of Guelph, Guelph, Ontario, N1G 2W1, Canada
}

\begin{abstract}
The study investigated the effect of chop length of wheat straw in a high-straw dry cow diet on the feeding behavior, health, and performance of Holstein dairy cows across the transition period. Forty cows were enrolled at dry off, approximately 45 d before expected calving, and assigned to 1 of 2 dietary treatments containing (on a dry matter basis) 36\% corn silage, $35 \%$ dry cow pellet, and $29 \%$ wheat straw. Diets were formulated to target an energy consumption of $19 \mathrm{Mcal} / \mathrm{d}$ of net energy for lactation per cow. The diets differed in the chop length of wheat straw: (1) long straw chopped with a 10.16-cm screen (LDD; $\mathrm{n}=20$ ), or (2) short straw chopped with a $2.54-\mathrm{cm}$ screen (SDD; $\mathrm{n}=20$ ). Dietary treatments were fed throughout the dry period. Feeding behavior, rumination time, and reticulorumen $\mathrm{pH}$ were monitored electronically, and feed samples were collected to determine feed sorting. Blood samples were taken weekly, and body condition scores and body weights were taken every 2 wk. Postcalving, all cows were fed the same lactating cow total mixed ration for $28 \mathrm{~d}$; the same measurements were recorded with the addition of daily milk yield and twice weekly milk components. During the dry period, cows fed the SDD treatment consumed more dry matter (15.6 vs. 15.0 $\mathrm{kg} / \mathrm{d}$ ), had more consistent dry matter intake in the week leading up to calving, had a faster feeding rate, consumed $0.4 \mathrm{~kg} /$ meal more, and had 0.6 fewer meals per day. No differences were observed in rumination time or mean reticulorumen $\mathrm{pH}$ between treatments in both the dry and lactating period. Regardless of treatment during the dry period, cows sorted against the long particles $(>19 \mathrm{~mm})$ and in favor of the short particles $(<8,>4 \mathrm{~mm})$, but cows fed the LDD treatment sorted to a greater extent than cows fed the SDD treatment. Dietary treatment in the dry period did not
\end{abstract}

Received May 29, 2019.

Accepted August 27, 2019.

*Corresponding author: tdevries@uoguelph.ca influence feed sorting behavior postcalving. Cows fed the LDD treatment had a greater daily change (decline) in rumen $\mathrm{pH}$ in the first week postcalving and had a greater blood $\beta$-hydroxybutyrate concentration in the third week postcalving. Overall, the results from this study indicate that feeding shorter chopped wheat straw in a high-straw dry cow diet improved intake, reduced sorting during the dry period, and resulted in greater metabolic health and rumen stability in early lactation.

Key words: transition period, feeding behavior, sorting

\section{INTRODUCTION}

The transition period, defined as 3 wk precalving to 3 wk postcalving (Drackley, 1999), is a challenging time for dairy cattle as it may be difficult for them to adapt to changes in energy demand and supply. Ensuring consistent feed intake across this time period reduces the risk of entering a state of negative energy balance (NEB) and, consequently, the risk of developing metabolic diseases, such as ketosis. Ketosis affects 2 to $15 \%$ of cows at the clinical level (Duffield, 2000) and 40 to $60 \%$ of cows at the subclinical level (McArt et al., 2012). Ketosis can lead to decreased milk production, poor reproductive performance, metabolic disorders, and infectious issues (Dohoo and Martin, 1984; Duffield, 2000). Promoting feed intake in an attempt to ensure that energy consumption meets demand can greatly reduce the risk of disease in the transition period.

Researchers have demonstrated that fresh cow DMI can be enhanced through a variety of nutritional means (Van Saun and Sniffen, 2014). In addition to modification of the lactating cow diet, we know that the diet consumed by dry cows may be equally important in terms of stimulating intake in early lactation and promoting a smooth transition (Goldhawk et al., 2009). A common trend in transition cow management is to feed dry cows a controlled-energy diet (Janovick and Drackley, 2010). One of the primary methods for controlling energy consumption to $100 \%$ of the cow's 
requirements in the dry period is through the incorporation of ingredients with low nutrient density, such as straw (Janovick et al., 2011). Although such diets have proved beneficial for promoting improved energy balance after calving (Janovick et al., 2011), from a cow feeding behavior standpoint, one potential area of concern with such a feeding strategy is the marked physical difference between the pre-fresh and post-fresh diets. The pre-fresh diet is bulky and low energy, whereas the post-fresh diet is usually more energy dense with smaller average particle size. Dietary selection (sorting) of TMR is a potential behavioral issue during the dry period and early lactation. Although not yet studied, dry cow diets that are high in straw and low in moisture content would be hypothesized to be more prone to sorting (Leonardi et al., 2005). This may lead to cows consuming a diet greater in energy density than intended, and this sorting behavior may persist into the fresh period. Much research suggests that chopping forages shorter will result in not only greater DMI (Maulfair and Heinrichs, 2013), but may also help to reduce the amount of feed sorting in lactating cow diets (Kononoff et al., 2003) and dry cow diets (Suarez-Mena et al., 2013). Thus, the primary objective of this study was to determine if pre-calving DMI is improved, if feed sorting is discouraged, and if consistency in DMI is maintained after calving by feeding high-straw dry cow diets with shorter chopped wheat straw. A secondary objective was to determine if rumen and metabolic health and postcalving performance are improved by feeding a dry cow diet with shorter chopped straw.

\section{MATERIALS AND METHODS}

\section{Animals and Housing}

Forty Holstein cows (parity $=1.5 \pm 0.88$; mean \pm SD) were used in this study, which took place at the University of Guelph Livestock Research and Innovation Centre-Dairy Facility (Elora, ON, Canada). At approximately $45 \mathrm{~d}$ before expected calving (actual $=$ $42.2 \pm 4.23 \mathrm{~d}$ ), cows were dried off and enrolled in the trial. The use of cows and experimental procedures complied with the guidelines of the Canadian Council on Animal Care (2009) and were approved by the University of Guelph Animal Care Committee (protocol \#3628).

During the dry period, cows were housed in 1 of 2 dry cow pens and trained to eat out of individually assigned automated feed bins (Insentec, B.V., Marknesse, the Netherlands). Throughout the duration of the study, both pens contained cows that were on either of the treatment diets. The dry cow pens each had 12 automated feed bins, 24 freestalls (mattress base, bed- ded with chopped wheat straw), and 2 water troughs. The stocking density of the pens never exceeded $100 \%$, ensuring each cow had access to a lying stall and their own automatic feed bin. Upon signs of calving, cows were moved to an individual maternity pen $(3.5 \times 4.9$ $\mathrm{m})$ where they had individual access to feed and water. Cows were in the maternity pen for $2.3 \pm 2.3 \mathrm{~d}$ before calving and $4.7 \pm 2.7 \mathrm{~d}$ after calving. After calving, cows were milked in their individual maternity pen using a portable milking system. After leaving the maternity pens, cows were moved to a lactating pen where they again were assigned and trained to an individual automated feed bin. The lactating pen had 15 automatic feed bins, 30 freestalls, and 2 water troughs. The stocking density never exceeded $100 \%$, which ensured that all cows had access to their own feed bin and a lying stall. Cows were milked $2 \times / \mathrm{d}$ at 0430 and $1615 \mathrm{~h}$ in a rotary milking parlor (DeLaval, Tumba, Sweden).

\section{Experimental Design}

Sample size and power analyses were used to calculate (as per Morris, 1999) the minimum number of replicates needed per treatment $(n=20)$ to detect a $10 \%$ level of observed mean difference for the primary outcome variables, including DMI, feeding behavior, and feed sorting. Estimates of variation for these variables were based on previously reported values (Suarez-Mena et al., 2013; Coon et al., 2018; Dancy et al., 2019).

Dry cows were fed a dry cow TMR (Table 1) $1 \times / d$ between 0930 and $1030 \mathrm{~h}$. The total amount of feed offered was adjusted daily to target $10 \%$ refusals per bin (actual $=18.0 \pm 12.8 \%$, on a DM basis). The dry cow bins were cleaned out daily at approximately 0900 h. Upon dry off, cows were randomly assigned to 1 of 2 dietary treatments (Table 1), a dry cow TMR that differed in the length of wheat straw: (1) short straw chopped with a $2.54-\mathrm{cm}$ screen (SDD; $\mathrm{n}=20$ ), or (2) long straw chopped with a 10.16-cm screen (LDD; n $=20$ ). Treatment allocation was balanced for parity and previous $305 \mathrm{~d}$ milk production $(9,879 \pm 1,651 \mathrm{~kg})$. Both treatment diets were formulated using Agricultural Modeling and Training Systems (AMTS.Cattle. Professional 4.10.5, New York, NY) to target an energy consumption of $19 \mathrm{Mcal} / \mathrm{cow}$ per $\mathrm{d}$ of $\mathrm{NE}_{\mathrm{L}}$ and were fed ad libitum for the entire dry period. Diets were formulated to target a negative DCAD value of $-245 \mathrm{mEq} /$ $\mathrm{kg}$, and urine $\mathrm{pH}$ was routinely measured to monitor effectiveness of the DCAD program. Furthermore, the diets were formulated to target a chloride level of $1.1 \%$ of the diet DM. Straw was chopped using a bale processor (Haybuster model H-1150, Jamestown, ND) using a 2.54-cm screen for the SDD and a 10.16-cm screen for the LDD. Base diets containing corn silage and dry cow 
concentrate were prepared in a mixer wagon (Jaylor model 5572, Jaylor Fabricating, Orton, ON, Canada) and then transferred to individual feed carts (Super Data Ranger, American Calan, Northwood, NH), where the straw specific to each of the treatments was added and the diet was mixed again. Upon calving, all cows were fed the same lactating cow ration (Table 1), $1 \times / \mathrm{d}$ between 1230 and $1330 \mathrm{~h}$. The total amount of feed offered was adjusted daily to target approximately $10 \%$ refusals per bin (actual $=17.6 \pm 13.8 \%$, on a DM basis). The lactating ration was formulated to meet the nutrient requirements of dairy cows producing $36 \mathrm{~kg} / \mathrm{d}$ (NRC, 2001), and cows were monitored for $28 \mathrm{~d}$. Particle size distribution and nutrient content by particle size of the offered experimental dry cow rations and lactating ration are shown in Table 2.

\section{Behavioral Data Collection}

Feeding behavior and DMI were monitored using the automated feed bins, as validated by Chapinal et al. (2007). From the recorded data, the duration of each visit to the feed bin, the amount of feed consumed (start weight - end weight) during each visit, and the rate of consumption for each visit were calculated. These data were then summarized to calculate DMI $(\mathrm{kg} / \mathrm{d})$, time spent feeding $(\mathrm{min} / \mathrm{d})$, and feeding rate $(\mathrm{kg} / \mathrm{min})$. Individual feeding bouts were combined and separated into meals using a meal criterion (i.e., the minimum duration of time between meals) calculated for each cow. Meal criteria for the dry period and lactating period were calculated for each cow using methods described by DeVries et al. (2003); a software package (MIX 3.1.3; MacDonald and Green, 1988) was used to fit normal distributions to the frequency of $\log _{10}$-transformed intervals of time between feeding visits. If the interval of time between 2 bin visits exceeded the determined meal criterion, this was classified as a different meal. The number of different meals in a day was termed meal frequency (no./d). Total meal time was the time between the start of the first bin visit until the end of the last bin visit, without exceeding the meal criterion. Meal length (min/meal) was calculated as the total meal time divided by the meal frequency. Finally, meal size $(\mathrm{kg} / \mathrm{d})$ was calculated as DMI divided by the meal frequency.

An electronic monitoring system (HR-TAG-LD, SCR Engineers Ltd., Netanya, Israel) was used in this study to monitor rumination activity, as validated by Schirmann et al. (2009). Rumination data loggers, attached to a nylon collar, were fitted to each cow before enrolment. Throughout the entire duration of the dry period and for 4 wk postcalving, rumination activity was monitored $24 \mathrm{~h} / \mathrm{d}$. The system contained a radio frequency reader, which allowed data from the collars to be continuously uploaded to the control unit. These data, stored in 2-h intervals, were used to determine total time spent ruminating throughout each day.

\section{Health Data Collection}

At the time of enrollment, and every 2 wk thereafter, cow BW was recorded using a scale (DeLaval) and BCS was recorded using a 5-point scale, as described by Wildman et al. (1982). One observer assessed BCS for the entire duration of the trial. All measurements were taken before feeding $(0930 \mathrm{~h}$ for dry cows and $1230 \mathrm{~h}$ for lactating cows).

Wireless telemetry boluses (eBolus, eCow Ltd., Devon, UK) were used to measure reticulorumen $\mathrm{pH}$ (as validated by Falk et al., 2016). Before calving, the boluses were administered to 16 cows orally using a balling gun (LDD, $\mathrm{n}=7$; SDD, $\mathrm{n}=9$ ). Data consisted of reticulorumen $\mathrm{pH}$ data readings at 15-min intervals 24 $\mathrm{h} / \mathrm{d}$ throughout the trial period. Data were downloaded weekly and amalgamated into a continuous record for each individual cow. Time spent below a $\mathrm{pH}$ threshold of 5.8 and area under the curve at a 5.8 threshold were then calculated (as per Dohme et al., 2008), along with daily mean, minimum, and maximum $\mathrm{pH}$ values.

Blood metabolites including BHB, calcium, glucose, nonesterified fatty acids (NEFA), and haptoglobin were assessed on $\mathrm{d}-33,-19,-12,1,4,7,10,13,19$, and 25 relative to calving. For blood sampling, cows were restrained in a stall to obtain blood into a $10-\mathrm{mL}$ Vacutainer tube from the coccygeal vein. Blood BHB was measured using an electronic handheld device (FreeStyle Precision Neo, Abbott Diabetes Care, Saint Laurent, QC, Canada), as validated by Kanz et al. (2015). Blood BHB concentrations $\geq 1.2 \mathrm{mmol} / \mathrm{L}$ were deemed indicative of subclinical ketosis (Geishauser et al., 1998; McArt et al., 2012). Cows were also routinely tested from d 7 to 14 for elevated BHB by farm staff using Keto-Test milk strips (KetoLac BHB, Sanwa Kagaku Kenkyusho Co., Higashi-Ku, Nagoya, Japan). Cows with readings $<100 \mu \mathrm{mol} / \mathrm{L}$ were untreated, 100 $<$ readings $<200 \mu \mathrm{mol} / \mathrm{L}$ were treated with a $300-\mathrm{mL}$ oral drench of propylene glycol for $3 \mathrm{~d}$, and readings $>200 \mu \mathrm{mol} / \mathrm{L}$ were treated with a $300-\mathrm{mL}$ oral drench of propylene glycol for $5 \mathrm{~d}$. Blood collection occurred before daily feeding $(0930 \mathrm{~h}$ for dry cows and $1230 \mathrm{~h}$ for lactating cows) throughout the study. All blood samples were left to sit at room temperature for a period of $1 \mathrm{~h}$ following collection to allow coagulation and to facilitate fibrinogen breakdown. After $1 \mathrm{~h}$, samples were centrifuged at $1,500 \times g$ at $18^{\circ} \mathrm{C}$ for $15 \mathrm{~min}$ to separate cells from serum. For each blood sample, 1.5 $\mathrm{mL}$ of serum was placed into $3-\mathrm{mL}$ tubes and frozen at 
Table 1. Ingredient and chemical composition (mean $\pm \mathrm{SD}$ ) of the treatment dry cow and the lactating cow TMR

\begin{tabular}{|c|c|c|c|}
\hline Composition & Long dry diet & Short dry diet & Lactating diet \\
\hline \multicolumn{4}{|l|}{ Ingredient (\% of DM) } \\
\hline Corn silage $^{1}$ & 36 & 36 & 32 \\
\hline Wheat straw ${ }^{2,3,4}$ & 29 & 29 & 2 \\
\hline Alfalfa haylage $^{5}$ & - & - & 31 \\
\hline High-moisture corn $^{6}$ & - & - & 22 \\
\hline Dry cow supplement ${ }^{7}$ & 35 & 35 & - \\
\hline Lactating cow supplement ${ }^{8}$ & - & - & 12 \\
\hline \multicolumn{4}{|l|}{ Chemical composition } \\
\hline $\mathrm{DM}(\%)$ & $58.8 \pm 3.89$ & $58.9 \pm 3.93$ & $46.3 \pm 2.34$ \\
\hline $\mathrm{CP}(\%$ of $\mathrm{DM})$ & $13.2 \pm 0.57$ & $13.2 \pm 0.67$ & $15.1 \pm 0.73$ \\
\hline $\mathrm{ADF}(\%$ of $\mathrm{DM})$ & $28.7 \pm 1.93$ & $29.7 \pm 1.30$ & $20.5 \pm 1.45$ \\
\hline NDF (\% of DM) & $44.4 \pm 2.25$ & $46.2 \pm 1.22$ & $30.9 \pm 0.87$ \\
\hline TDN (\% of DM) & $66.5 \pm 1.51$ & $65.8 \pm 1.01$ & $72.9 \pm 1.13$ \\
\hline Lignin (\% of DM) & $3.4 \pm 0.34$ & $4.4 \pm 0.38$ & $3.0 \pm 0.36$ \\
\hline Starch (\% of DM) & $16.6 \pm 1.12$ & $16.0 \pm 2.0$ & $27.8 \pm 1.70$ \\
\hline Fat $(\%$ of DM $)$ & $2.9 \pm 0.34$ & $2.8 \pm 0.41$ & $3.5 \pm 0.22$ \\
\hline Ash (\% of DM) & $8.6 \pm 0.47$ & $8.3 \pm 0.46$ & $7.3 \pm 0.46$ \\
\hline $\mathrm{Ca}(\%$ of $\mathrm{DM})$ & $1.3 \pm 0.27$ & $1.3 \pm 0.21$ & $1.0 \pm 0.09$ \\
\hline $\mathrm{P}(\%$ of $\mathrm{DM})$ & $0.3 \pm 0.02$ & $0.3 \pm 0.02$ & $0.5 \pm 0.03$ \\
\hline $\mathrm{K}(\%$ of $\mathrm{DM})$ & $1.1 \pm 0.07$ & $1.1 \pm 0.04$ & $1.6 \pm 0.06$ \\
\hline $\mathrm{Na}(\%$ of $\mathrm{DM})$ & $0.1 \pm 0.02$ & $0.1 \pm 0.01$ & $0.4 \pm 0.02$ \\
\hline $\mathrm{Mg}(\%$ of $\mathrm{DM})$ & $0.5 \pm 0.04$ & $0.5 \pm 0.04$ & $0.4 \pm 0.01$ \\
\hline uNDF240h $(\% \text { of DM })^{9}$ & $12.6 \pm 1.51$ & $12.0 \pm 1.01$ & $10.8 \pm 1.28$ \\
\hline NDFD240h $(\% \text { of NDF })^{10}$ & $71.7 \pm 0.95$ & $74.0 \pm 2.72$ & $65.1 \pm 3.43$ \\
\hline $\mathrm{NE}_{\mathrm{L}}(\mathrm{Mcal} / \mathrm{kg}$ of $\mathrm{DM})$ & $1.51 \pm 0.04$ & $1.50 \pm 0.03$ & $1.67 \pm 0.03$ \\
\hline
\end{tabular}

${ }^{1}$ Corn silage had a DM of $37.6 \%$ and chemical composition (DM basis) $8.5 \% \mathrm{CP}, 22.5 \% \mathrm{ADF}$, and $39.1 \%$ NDF. Particle size distribution $(\%$ of $\mathrm{DM})=10.7 \pm 4.76 \%$ long $(>19 \mathrm{~mm}), 68.5 \pm 7.52 \%$ medium $(<19,>8 \mathrm{~mm})$, $11.6 \pm 2.22 \%$ short $(<8,>4 \mathrm{~mm})$, and $9.1 \pm 3.09 \%$ fine $(<4 \mathrm{~mm})$ particles.

${ }^{2}$ Long straw (chopped with a 10.16-cm screen) had a DM of $90.2 \%$ and chemical composition (DM basis) $4.7 \%$ $\mathrm{CP}, 56.7 \% \mathrm{ADF}$, and $82.2 \% \mathrm{NDF}$. Particle size distribution (\% of DM) $=29.8 \pm 7.16 \%$ long $(>19 \mathrm{~mm}), 35.4$ $\pm 2.40 \%$ medium $(<19,>8 \mathrm{~mm}), 17.1 \pm 2.05 \%$ short $(<8,>4 \mathrm{~mm}), 17.7 \pm 4.55 \%$ fine $(<4 \mathrm{~mm})$ particles.

${ }^{3}$ Short straw (chopped with a $2.54-\mathrm{cm}$ screen) had a DM of $90.3 \%$ and chemical composition (DM basis) $5.1 \%$ $\mathrm{CP}, 54.5 \% \mathrm{ADF}$, and $81.8 \% \mathrm{NDF}$. Particle size distribution $(\%$ of $\mathrm{DM})=4.8 \pm 8.22 \%$ long $(>19 \mathrm{~mm}), 36.5$ $\pm 8.77 \%$ medium $(<19,>8 \mathrm{~mm}), 25.1 \pm 4.36 \%$ short $(<8,>4 \mathrm{~mm}), 33.6 \pm 9.22 \%$ fine $(<4 \mathrm{~mm})$ particles.

${ }^{4}$ Lactating straw had a DM of $89.0 \%$ and chemical composition (DM basis) $5.1 \%$ CP, $55.7 \%$ ADF, and $82.3 \%$ NDF. Particle size distribution $(\%$ of $\mathrm{DM})=8.7 \pm 3.79 \%$ long $(>19 \mathrm{~mm}), 40.2 \pm 3.24 \%$ medium $(<19,>8$ $\mathrm{mm}), 22.8 \pm 1.08 \%$ short $(<8,>4 \mathrm{~mm})$, and $28.3 \pm 4.98 \%$ fine $(<4 \mathrm{~mm})$ particles.

${ }^{5}$ Alfalfa haylage had a DM of $36.8 \%$ and chemical composition (DM basis) $21.3 \% \mathrm{CP}, 34.1 \% \mathrm{ADF}$, and $42.0 \%$ NDF. Particle size distribution $(\%$ of $\mathrm{DM})=43.4 \pm 7.91 \%$ long $(>19 \mathrm{~mm}), 40.9 \pm 6.75 \%$ medium $(<19,>8$ $\mathrm{mm}), 9.4 \pm 1.55 \%$ short $(<8,>4 \mathrm{~mm})$, and $6.3 \pm 2.79 \%$ fine $(<4 \mathrm{~mm})$ particles.

${ }^{6}$ High-moisture corn had a DM of $76.7 \%$ and chemical composition (DM basis) $9.5 \% \mathrm{CP}, 2.3 \%$ ADF, and $8.2 \%$ NDF.

${ }^{7}$ Supplied by Floradale Feed Mill Ltd. (Floradale, Ontario, Canada) including ingredients (as fed); $24.7 \%$ SoyPlus (Landus Cooperative, Ames, IA), 10.9\% Animate (Phibro, Teaneck, NJ), $11.2 \%$ ground soy hulls, $10.1 \%$ beet pulp, $9.8 \%$ canola, $8.2 \%$ oat hulls, $6.9 \%$ soybean meal, $7.0 \%$ limestone calcium carbonate, $5.0 \%$ bran, $2.0 \%$ molasses, $1.2 \%$ Diamond V Yeast XP (Diamond V, Cedar Rapids, IA), $0.9 \%$ calcium sulfate, $0.7 \%$ fine salt, $0.6 \%$ vitamin $\mathrm{E}, 0.3 \%$ selenium, $0.23 \%$ FFM ruminant micro premix (Floradale), $0.2 \%$ magnesium oxide, $0.03 \%$ Rumensin/Coban (Elanco, Greenfield, IN), and 0.01\% Rovimix Biotin 20000 (H2; DSM, Herleen, the Netherlands). Dry cow supplement had a DM of $91.5 \%$ and chemical composition (DM basis) $27.0 \% \mathrm{CP}$, $16.7 \% \mathrm{ADF}$, and $28.7 \% \mathrm{NDF}$.

${ }^{8}$ Supplied by Floradale Feed Mill Ltd. (Floradale) including ingredients (as fed); $34.5 \%$ SoyPlus (Landus Cooperative), $31.5 \%$ soybean meal, $14.7 \%$ canola, $4.0 \%$ sodium sesquicarbonate, $3.7 \%$ limestone calcium carbonate, $3.7 \%$ fine salt, $2.2 \%$ monocalcium phosphate, $1.9 \%$ magnesium oxide, $1.8 \%$ Diamond V Yeast XP (Diamond V), 0.9\% FFM Org Ruminant Micro PRX (Floradale), 0.8\% MetaSmart (Adisseo, Alpharetta, GA), $0.3 \%$ granular sulfur, 0.04\% Rumensin/Corban (Elanco), 0.04\% Selplex 2000 (Alltech, Nicholasville, KY). Lactating cow supplement had a DM of $90.8 \%$ and chemical composition (DM basis) $37.1 \%$ CP, $9.0 \%$ ADF, and $18.0 \% \mathrm{NDF}$.

${ }^{9} \mathrm{uNDF} 240 \mathrm{~h}=$ undigested NDF, estimated via 240 -h in vitro fermentation.

${ }^{10} \mathrm{NDFD} 240 \mathrm{~h}=$ in vitro NDF digestibility after $240 \mathrm{~h}$ of incubation.

$-20^{\circ} \mathrm{C}$ until the time of analysis. Serum samples were sent to the Animal Health Laboratory, University of Guelph, where they were analyzed for NEFA (reagent supplied by Randox Laboratories, Crumlin, UK), glucose (reagent supplied by Roche, Indianapolis, IN), calcium (reagent supplied by Roche), and haptoglobin 
(reagent created and shared by the J.G. Skinner Laboratory, Veterinary Investigation Centre, Aberdeen, UK) using a photometric test on the Roche Cobas 6000 c501 instrument (Roche).

\section{Milk Yield and Components}

Following calving, milk yield was recorded at every milking in the milking parlor (DeLaval) for the 4-wk period postcalving. Milk samples were collected from each cow, at each milking, on 2 consecutive days starting at 5 DIM. Two samples were taken on d 5, 6, 12, 13, 19, 20, 26, and 27 postcalving. These samples were sent to a DHI testing laboratory (CanWest DHI, Guelph, ON, Canada) for component analysis (fat, protein, MUN and SCC) using a Fourier Transform Infrared full spectrum analyzer (Milkoscan FT+ and Milkoscan 6000, Foss, Hillerod, Denmark). One value per cow on each sampling day was calculated; these were adjusted based on milk weights per milking.

Milk composition samples were used to determine the yield of $4 \% \mathrm{FCM}(\mathrm{kg} / \mathrm{d})$, calculated as $[0.4 \times$ milk yield $(\mathrm{kg} / \mathrm{d})]+[15.0 \times$ fat yield $(\mathrm{kg} / \mathrm{d})](\mathrm{NRC}, 2001)$. Energy-corrected milk was calculated as ECM $(\mathrm{kg} / \mathrm{d})$ $=(0.327 \times \mathrm{kg}$ of milk $)+(12.95 \times \mathrm{kg}$ of fat $)+(7.2 \times$ $\mathrm{kg}$ of protein) (Tyrrell and Reid, 1965). Efficiency of milk production was calculated as kilograms of milk, $4 \%$ FCM yield, and ECM yield per kilogram of DMI per cow.

\section{Feed Sampling and Analysis}

Throughout the study, fresh feed samples of each diet (dry treatment diets and lactating diet) were taken in duplicate $3 \times /$ wk; 1 sample was collected to determine DM and chemical composition, and the other sample was collected to determine particle size distribution. Samples of the TMR components were also collected once monthly to be analyzed for DM, chemical composition, and particle size distribution. During the dry period, orts samples were collected $2 \times /$ wk from each cow to determine particle distribution for calculation of sorting. Upon calving, orts samples were taken every day for the first 7 DIM and then $2 \times /$ wk for the remainder of the study. All feed samples were immediately frozen at $-20^{\circ} \mathrm{C}$ until further analysis.

After a 24-h period of thawing, fresh and orts TMR samples collected for particle size analysis were processed using a 4-screen Penn State Particle Separator (PSPS; Maulfair et al., 2011), which separated the sample into 4 fractions based on particle size: long $(>19$ $\mathrm{mm})$, medium $(<19,>8 \mathrm{~mm})$, short $(<8,>4 \mathrm{~mm})$, and

Table 2. Particle size distribution ${ }^{1}$ (mean $\pm \mathrm{SD}$ ), and nutrient content (mean \pm SD) by particle size of the fresh experimental diets ${ }^{2}$

\begin{tabular}{|c|c|c|c|}
\hline Item & Long dry diet & Short dry diet & Lactating diet \\
\hline \multicolumn{4}{|c|}{$\%$ as fed retained on screen ${ }^{1}$} \\
\hline Long & $15.3 \pm 4.69$ & $4.3 \pm 2.27$ & $13.3 \pm 5.52$ \\
\hline Medium & $45.2 \pm 5.43$ & $50.1 \pm 5.38$ & $52.1 \pm 4.66$ \\
\hline Short & $14.7 \pm 1.97$ & $17.8 \pm 1.76$ & $15.1 \pm 1.37$ \\
\hline Fine & $25.4 \pm 4.77$ & $29.2 \pm 9.15$ & $20.9 \pm 3.27$ \\
\hline \multicolumn{4}{|c|}{$\%$ of DM retained on screen ${ }^{1}$} \\
\hline Long & $15.2 \pm 4.26$ & $3.3 \pm 1.67$ & $10.8 \pm 3.56$ \\
\hline Medium & $43.3 \pm 6.05$ & $47.4 \pm 5.72$ & $48.8 \pm 3.93$ \\
\hline Short & $15.3 \pm 1.50$ & $19.4 \pm 2.91$ & $16.3 \pm 1.13$ \\
\hline Fine & $26.2 \pm 4.75$ & $30.0 \pm 5.08$ & $24.0 \pm 3.45$ \\
\hline \multicolumn{4}{|c|}{$\mathrm{ADF}^{3}(\%$ of screen DM) } \\
\hline Long & $43.4 \pm 1.60$ & $34.2 \pm 4.18$ & $30.0 \pm 1.11$ \\
\hline Medium & $29.9 \pm 0.62$ & $29.4 \pm 2.43$ & $24.1 \pm 0.70$ \\
\hline Short & $25.8 \pm 1.05$ & $31.0 \pm 2.93$ & $16.1 \pm 0.49$ \\
\hline Fine & $22.3 \pm 1.01$ & $27.6 \pm 1.02$ & $12.0 \pm 0.14$ \\
\hline \multicolumn{4}{|c|}{$\mathrm{NDF}^{3}$ (\% of screen DM) } \\
\hline Long & $65.7 \pm 1.23$ & $54.9 \pm 5.26$ & $41.9 \pm 0.24$ \\
\hline Medium & $46.8 \pm 1.36$ & $46.6 \pm 3.41$ & $35.8 \pm 0.62$ \\
\hline Short & $41.3 \pm 1.70$ & $48.5 \pm 4.18$ & $27.0 \pm 0.23$ \\
\hline Fine & $35.3 \pm 0.69$ & $41.9 \pm 2.26$ & $19.8 \pm 0.21$ \\
\hline $\operatorname{peNDF}_{8 \mathrm{~mm}}{ }^{4}(\%)$ & $25.8 \pm 2.30$ & $23.1 \pm 3.20$ & $18.5 \pm 1.33$ \\
\hline $\operatorname{peNDF}_{4 \mathrm{~mm}}(\%)$ & $32.6 \pm 2.60$ & $32.0 \pm 3.57$ & $23.5 \pm 1.13$ \\
\hline
\end{tabular}

${ }^{1}$ Particle size determined by processing feed samples with the Penn State Particle Separator (Maulfair et al., 2011), which has a 19-mm screen (long), 8-mm screen (medium), 4-mm screen (short), and a pan (fine).

${ }^{2}$ Long dry diet $=$ TMR with straw chopped with a 10.16-cm screen; short dry diet = TMR chopped with 2.54cm screen.

${ }^{3}$ Values were obtained from chemical analysis of TMR samples separated by particle size with Penn State Particle Separator.

${ }^{4}$ peNDF $=$ physically effective NDF; ration NDF multiplied by DM $>4$ and $8 \mathrm{~mm}$. 
fine $(<4 \mathrm{~mm})$. Separated samples were then oven-dried at $55^{\circ} \mathrm{C}$ for $48 \mathrm{~h}$.

The sorting of each PSPS fraction was calculated (as per Leonardi and Armentano, 2003) by dividing the actual amount of feed consumed of each fraction by the predicted amount of feed consumed of that fraction and expressing it as a percentage. For each fraction, the actual amount consumed was calculated by subtracting the DM refused from the DM offered, as determined by the PSPS analyses. The predicted amount consumed for each fraction was calculated as the product of the DMI of the total diet multiplied by the DM percentage of that fraction in the fed TMR. If the sorting value equaled $100 \%$, then no sorting of the particle fraction occurred, a value $<100 \%$ indicated sorting against that particle size fraction, whereas a value $>100 \%$ indicated sorting in favor of that particle fraction.

Feed samples collected for nutrient composition analysis included the fresh TMR samples, feed components, and fresh TMR PSPS fractions. Following oven drying at $55^{\circ} \mathrm{C}$ for $48 \mathrm{~h}$, these samples were ground to pass through a 1-mm screen (model 4 Wiley Laboratory Mill, Thomas Scientific, Swedesboro, NJ). Ground samples, pooled by week, were then sent to A\&L Laboratory Services Inc. (London, ON, Canada) for analysis of ash $\left(550^{\circ} \mathrm{C}\right.$; AOAC International, 2000: method 942.05), ADF (AOAC International, 2000: method 973.18), NDF with heat-stable $\alpha$-amylase and sodium sulfite (AOAC International, 2000: method 2002.04), CP (N $\times 6.25$; AOAC International, 2000: method 990.03; Leco FP-628 Nitrogen Analyzer, Leco, St. Joseph, $\mathrm{MI})$, starch (heat-stable amylase and amyloglucosidase; AOAC International, 2000: method 996.11), fat (using pet ether, AOAC International, 2000: method 920.39), lignin (using $\mathrm{ADF}$ residue and $\mathrm{H}_{2} \mathrm{SO}_{4}$ ), and minerals (using aquaregia digestion inductively coupled plasma atomic emission spectroscopy), and calculation of TDN and net energy (using NRC, 2001, equations).

\section{Statistical Analyses}

All statistical analyses were conducted using SAS 9.4 software (SAS Institute Inc., 2013). Due to technical failure of reticulorumen $\mathrm{pH}$ boluses, complete data sets were not available for all cows. Remaining analyses were conducted using a sample size of 15 cows (LDD, $\mathrm{n}$ $=7$; SDD, $\mathrm{n}=8$ ). Due to technical failure of 1 rumination collar, remaining analyses were conducted using a sample size of 39 cows (LDD, $\mathrm{n}=20$; SDD, $\mathrm{n}=19$ ). Before analyses, data were screened for normality using the UNIVARIATE procedure of SAS; most variables met the assumptions for normality except for SCC, haptoglobin, and area under the curve for time spent below $\mathrm{pH}$ thresholds. The natural logarithm of these variables was calculated and used to achieve normality. Prior to transformation, a value of 1 was added to all values for area under the curve spent below $\mathrm{pH}$ thresholds to ensure the natural logarithm could be calculated for data points that were calculated to be 0 . Postcalving, 4 cows were diagnosed with milk fever, 3 cows with retained placenta, 3 cows with mastitis, and 1 cow with lameness; all cows remained in the statistical analyses because of similar distribution of health problems between treatments and none of these cows' daily data were outliers. Significance was declared at $P \leq 0.05$ and tendencies were reported if $0.05<P \leq$ 0.10 . If the $P$-value of an interaction term was $\leq 0.05$, it was considered, otherwise interaction terms were disregarded.

To investigate the effect of dietary treatment on feed sorting, feeding behavior, DMI, rumination, reticulorumen $\mathrm{pH}$, blood metabolites, BW, BCS, milk production, and milk composition, data were first organized by status (dry or lactating) and then summarized either by day or by week (depending on sampling frequency) and analyzed using the MIXED procedure of SAS, by status, treating week or day as a repeated measure and cow as the subject of the repeated statement. The model included the fixed effects of week/day, treatment, and the week/day $\times$ treatment interaction. Previous 305-d milk production, parity, and BW were added to the milk production and component models. Enrollment BW was added as a covariate to the DMI model in the dry period, and postcalving BW was added as a covariate to the DMI model in the lactating period. Covariance structure was selected on the basis of best fit according to Schwarz's Bayesian information criterion. The PDIFF option was used in the LSMEANS statement for analyzing differences between treatments, within week, when week $\times$ treatment interactions were detected. To determine the occurrence of sorting within treatments, the summarized data for each particle size were averaged by week and tested for a difference from 100 using $t$-tests, using the previously described MIXED procedure model.

To determine if there was a treatment effect on BW and BCS, models were created using the MIXED procedure, wherein BW and BCS at the start of the study, before calving, postcalving, and at the end of the trial were used as dependent variables and treatment was used as a fixed effect. Changes in BW and BCS were also calculated at 3 time points: (1) from dry off to precalving, (2) from dry off to postcalving, and (3) from postcalving to the end of the trial.

Given that DMI often drops in the week before calving (Grummer, 1995; Drackley, 1999), the change in DMI from $\mathrm{d}-7$ to -1 was modeled. To model this change, an analysis of covariance was conducted to determine if 
there were significant linear, quadratic, or cubic effects of day (as per Schwaiger et al., 2013; DeVries et al., 2014a); this was done by using the MIXED procedure of SAS. The fixed effects of treatment, day, treatment $\times$ day, day ${ }^{2}$, treatment $\times$ day $^{2}$, day $^{3}$, and treatment $\times$ day ${ }^{3}$ were tested with the random effect of cow. Starting with the highest order term, those terms that were nonsignificant $(P>0.05)$ were removed from the model in a stepwise manner until only significant $(P \leq 0.05)$ terms remained in the model. When an interaction was significant, the lower order term was removed. Likewise, the transition from a low-energy, high-straw diet to an energy-dense diet can alter the rumen environment (Humer et al., 2015). As such, the change in rumen $\mathrm{pH}$ from $d-7$ to $d 7$ was modeled using the same approach listed above.

\section{RESULTS}

\section{Dry Period}

Cows fed the SDD treatment had greater DMI compared with cows fed the LDD treatment (Table 3; Figure 1). The change in DMI in the week leading up to calving was modeled, and the fitted data indicated treatment differences for cubic coefficients $(P<0.001$; Figure 2), with LDD cows experiencing a greater drop in DMI during this time period. Cows fed the SDD had greater NDF intake (NDFI) as a \% of BW compared with cows fed the LDD treatment (0.91 vs. $0.82 \mathrm{~kg}$ of $\mathrm{NDFI} / \mathrm{kg}$ of BW; $\mathrm{SE}=0.01 ; P<0.001)$ and tended to do so when expressed as an amount of DM consumed (7.1 vs. $6.7 \mathrm{~kg}$ of NDFI; $\mathrm{SE}=0.16 ; P=0.06$ ). Cows fed the SDD treatment also tended to spend less time ruminating per unit of NDF consumed compared with cows fed the LDD treatment $(\mathrm{SDD}=71.7 \pm 1.87 \mathrm{~min} /$ $\mathrm{kg}$ of NDFI; LDD $=76.5 \pm 1.8 \mathrm{~min} / \mathrm{kg}$ of NDFI, $P=$ $0.08)$. Cows consumed $55.1 \pm 1.85 \%$ and $47.2 \pm 1.89 \%$ more energy than required, for SDD and LDD treatments, respectively, when expressed as $100 \%$ of their energy requirement $(P=0.005)$. Further, cows consumed $41.0 \pm 1.68 \%$ and $33.8 \pm 1.72 \%$ more energy, for SDD and LDD treatments, respectively, than required when expressed as $110 \%$ of their energy requirements $(P=0.005)$.

Cows fed the SDD treatment tended to eat faster, have longer meals, have fewer meals per day, and have a longer interval between meals than cows fed the LDD treatment (Table 3). Last, cows fed the SDD treatment had greater meal size than cows fed the LDD treatment. No difference in BW was detected between treatments at dry off $(\mathrm{LDD}=797.4 \pm 16.9 \mathrm{~kg} ; \mathrm{SDD}=777.2 \pm$ $16.9 \mathrm{~kg}$ ), and regardless of treatment, cows gained BW $(\mathrm{LDD}=41.5 \pm 5.00 \mathrm{~kg} ; \mathrm{SDD}=51.5 \pm 5.00 \mathrm{~kg} ; P=$

Table 3. Effect of straw particle size fed throughout the dry period on various measures of feeding behavior recorded across the dry period and the first $28 \mathrm{~d}$ of lactation $(\text { mean } \pm \mathrm{SE})^{1}$

\begin{tabular}{|c|c|c|c|c|c|}
\hline Item & \multicolumn{2}{|c|}{ Treatment $^{2}$} & \multicolumn{3}{|c|}{$P$-value } \\
\hline \multicolumn{6}{|l|}{ Dry period } \\
\hline DMI (kg/d) & $15.0 \pm 0.16$ & $15.6 \pm 0.16$ & $<0.001$ & 0.02 & 0.34 \\
\hline Feeding time $(\min / \mathrm{d})$ & $204.7 \pm 8.08$ & $205.5 \pm 8.08$ & $<0.001$ & 0.95 & 0.02 \\
\hline Feeding rate $(\mathrm{kg}$ of $\mathrm{DM} / \mathrm{min})$ & $0.08 \pm 0.002$ & $0.09 \pm 0.002$ & 0.56 & 0.09 & 0.92 \\
\hline Meal frequency (meals/d) & $6.3 \pm 0.23$ & $5.7 \pm 0.23$ & $<0.001$ & 0.06 & 0.29 \\
\hline Meal size (DM/meal) & $2.5 \pm 0.13$ & $2.9 \pm 0.13$ & $<0.001$ & 0.04 & 0.17 \\
\hline Interval between meals (min) & $184.1 \pm 11.05$ & $206.6 \pm 8.40$ & $<0.001$ & 0.07 & 0.38 \\
\hline Rumination $^{4}(\mathrm{~min} / \mathrm{d})$ & $500.4 \pm 8.01$ & $496.4 \pm 8.20$ & $<0.001$ & 0.73 & 0.95 \\
\hline \multicolumn{6}{|l|}{ Lactating period } \\
\hline DMI $(\mathrm{kg} / \mathrm{d})$ & $20.4 \pm 0.49$ & $19.6 \pm 0.49$ & $<0.001$ & 0.25 & 0.63 \\
\hline Feeding time $(\mathrm{min} / \mathrm{d})$ & $185.2 \pm 8.20$ & $188.4 \pm 8.16$ & $<0.001$ & 0.78 & 0.66 \\
\hline Feeding rate $(\mathrm{kg}$ of $\mathrm{DM} / \mathrm{min})$ & $0.1 \pm 0.01$ & $0.1 \pm 0.01$ & $<0.001$ & 0.36 & 0.03 \\
\hline Rumination $^{4}(\mathrm{~min} / \mathrm{d})$ & $516.7 \pm 8.80$ & $507.6 \pm 9.05$ & $<0.001$ & 0.47 & 0.99 \\
\hline
\end{tabular}

${ }^{1}$ Long dry diet, $\mathrm{n}=20$ cows; short dry diet, $\mathrm{n}=20$ cows.

${ }^{2}$ Long dry diet $=$ TMR with straw chopped with a 10.16-cm screen; short dry diet $=$ TMR with straw chopped with a $2.54-\mathrm{cm}$ screen.

${ }^{3} \mathrm{~T}=$ treatment.

${ }^{4}$ Long dry diet, $\mathrm{n}=20$ cows; short dry diet, $\mathrm{n}=19$ cows. 

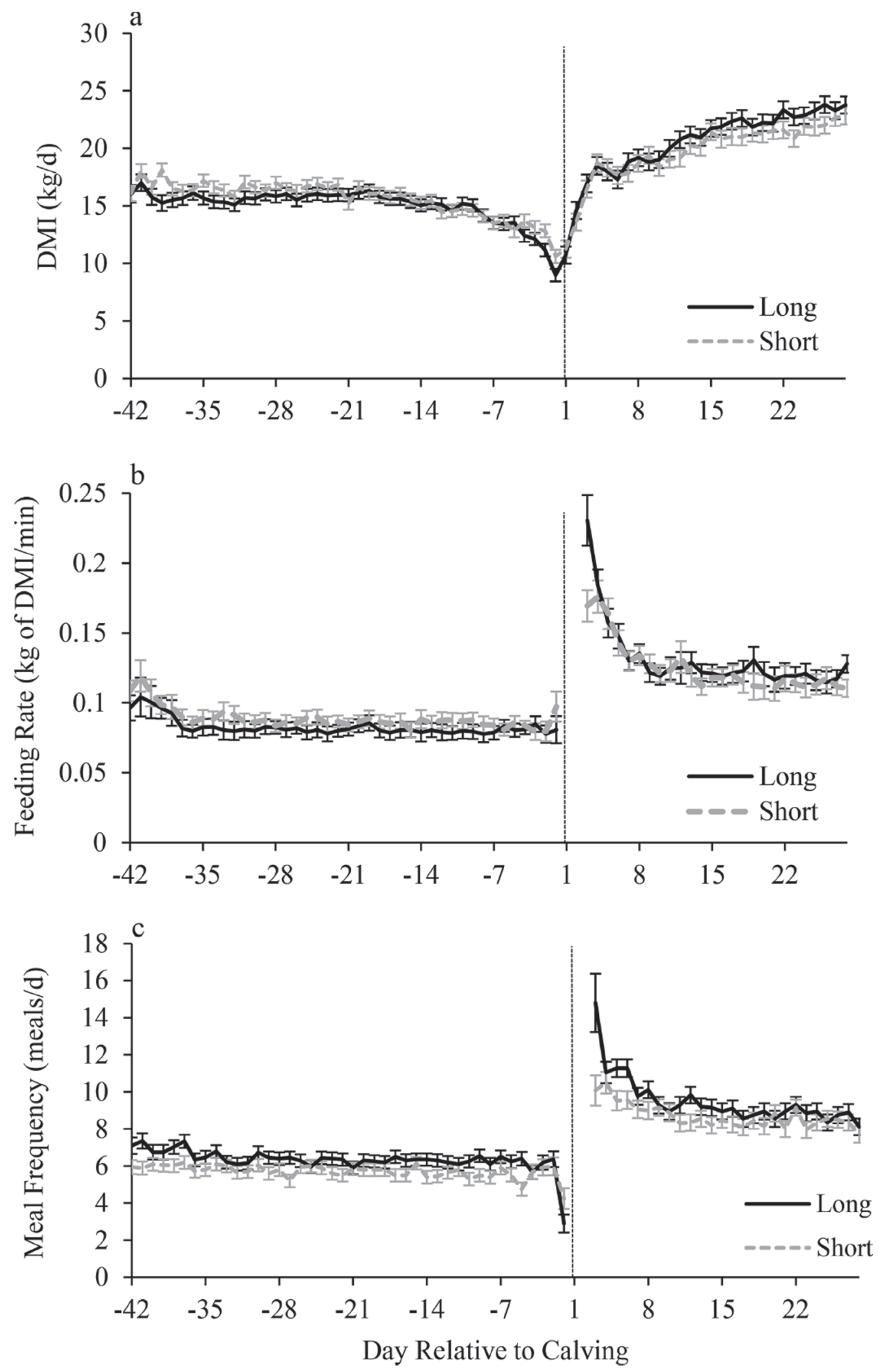

Figure 1. Daily (mean $\pm \mathrm{SE})$ : (a) DMI $(\mathrm{kg} / \mathrm{d})$, (b) feeding rate $(\mathrm{kg}$ of DMI/min), and (c) meal frequency for cows fed 1 of 2 dietary treatments during the dry period that differed in chop length of wheat straw [long dry diet (Long) = TMR with straw chopped with a 10.16-cm screen, $\mathrm{n}=20$; short dry diet (Short) $=$ TMR with straw chopped with a 2.54-cm screen, $\mathrm{n}=20]$; upon calving all cows were fed the same lactating cow ration. The vertical line represents day of calving. 


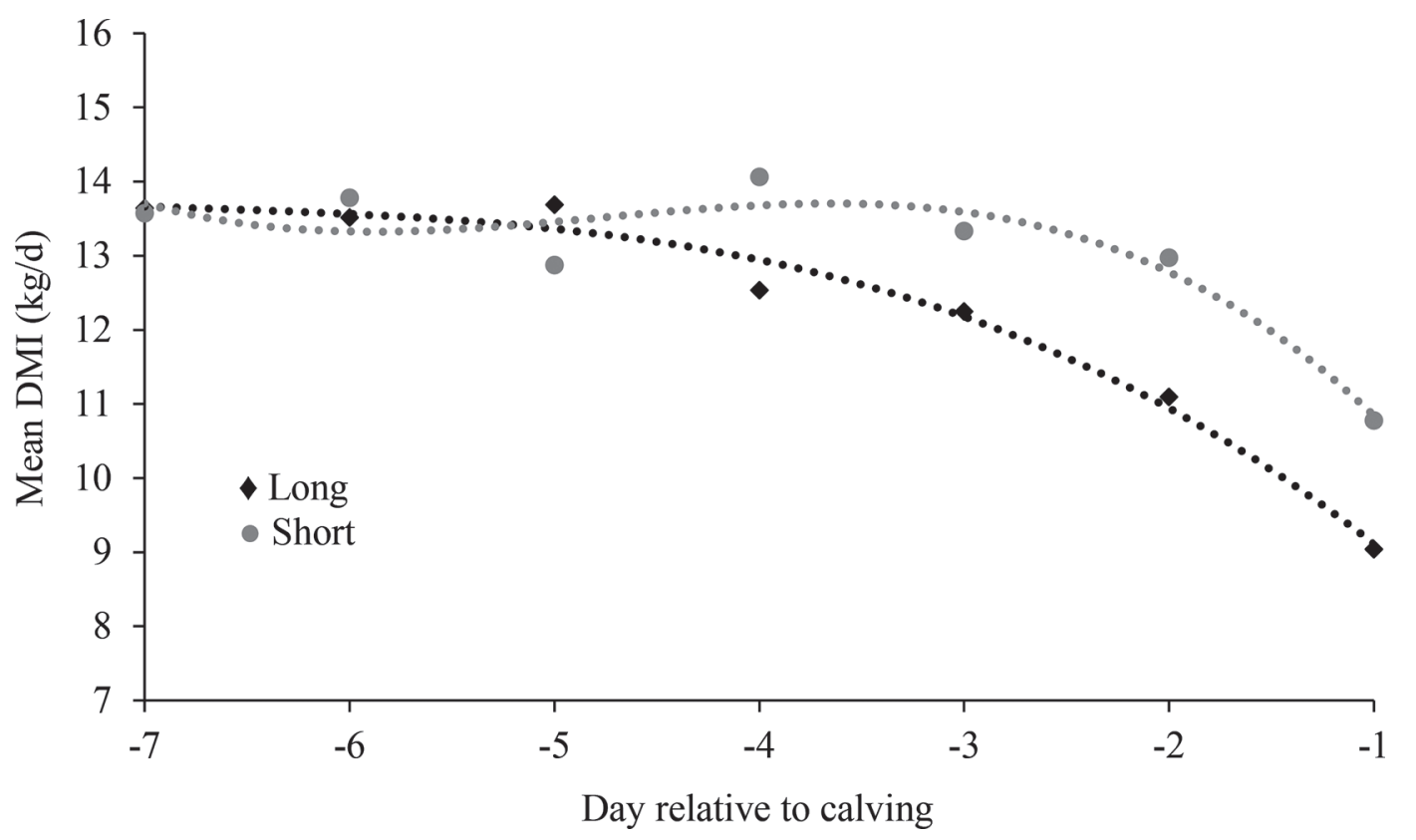

Figure 2. Mean daily DMI in the week leading up to calving when fed dry cow diets differing in chop length of wheat straw: (1) chopped with a $2.54-\mathrm{cm}$ screen [short dry diet (Short), $\mathrm{n}=20$ ] or $(2)$ chopped with a 10.16-cm screen [long dry diet (Long), $\mathrm{n}=20$ ]. Trend lines were constructed using analysis of covariance: $\mathrm{y}=0.70 \mathrm{~d}+0.09 \mathrm{~d}^{2}-0.008 \mathrm{~d}^{3}+12.89\left(\mathrm{R}^{2}=0.89\right)$ for the short dry diet; $\mathrm{y}=0.75 \mathrm{~d}-0.09 \mathrm{~d}^{2}-0.008 \mathrm{~d}^{3}+$ $12.74\left(\mathrm{R}^{2}=0.98\right)$ for the long dry diet.

$0.17)$ and $\mathrm{BCS}(\mathrm{LDD}=0.4 \pm 0.04$ units; $\mathrm{SDD}=0.1 \pm$ 0.04 units; $P=0.26$ ) throughout the dry period.

During the dry period, across treatments, cows sorted against the longest ration particles $(>19 \mathrm{~mm}$; Table $4)$. Cows fed the LDD treatment sorted against these longest particles to a greater extent than cows fed the SDD treatment. Cows fed the LDD and SDD treatment sorted in favor of the medium particles $(<19,>8$ $\mathrm{mm}$ ) to a similar extent. Regardless of treatment, cows sorted in favor of the short particles $(<8,>4 \mathrm{~mm})$; cows fed the LDD treatment sorted for these short particles to a greater extent than cows fed the SDD treatment. Cows fed the LDD treatment did not sort for or against the fine particles $(<4 \mathrm{~mm})$; however, cows fed the SDD treatment sorted against the fine particles in the dry cow ration. No effect was detected of treatment on measures of reticulorumen $\mathrm{pH}$ (Table 5) or blood parameters (Table 6) during the dry period.

\section{Lactating Period}

During the first $28 \mathrm{~d}$ of lactation, no difference was detected in DMI between treatments (Table 3). Cows previously fed the SDD treatment had fewer meals per day and had a longer interval between meals than cows fed the LDD treatment. No effect of treatment was detected on time spent ruminating per day during the lactating period (Table 3).
During the first week of lactation, no differences in sorting behavior were detected between treatments (Table 4); however, sorting did vary by day across treatments. For the first 7 d postpartum, cows sorted in favor of the long particles and against the fine ration particles (Figure 3). Cows sorted more in favor of the long particles for the first few days postpartum and started to sort less in favor of these particles toward the end of their first week postpartum $(P=0.01)$. Cows sorted more against the fine particles on $\mathrm{d} 1$ and started sorting less against the fine particles as they approached d $7(P<0.001$; Figure 3$)$.

No difference in postcalving BW was detected between treatments $(\mathrm{LDD}=760.3 \pm 15.3 \mathrm{~kg} ; \mathrm{SDD}=$ $742.7 \pm 15.7 \mathrm{~kg} ; P=0.43)$. On both treatments, cows lost $\mathrm{BW}(\mathrm{LDD}=46.9 \pm 8.03 \mathrm{~kg} ; \mathrm{SDD}=60.6 \pm 8.24$ $\mathrm{kg} ; P=0.23)$ and $\mathrm{BCS}(\mathrm{LDD}=0.2 \pm 0.04$ units; SDD $=0.2 \pm 0.04$ units; $P=0.25)$ during the first $28 \mathrm{~d}$ of lactation.

No effect was detected of treatment on mean, minimum, or maximum daily reticulorumen $\mathrm{pH}$ during the first $28 \mathrm{~d}$ of lactation (Table 5). Also, no difference was detected between treatments in daily time spent below a reticulorumen $\mathrm{pH}$ of 5.8 or 6.0 or area under the curve for a reticulorumen $\mathrm{pH}$ of 5.8 or 6.0 (Table 6 ). The change in reticulorumen $\mathrm{pH}$ for the first week postcalving was modeled, and the fitted data indicated treatment differences for cubic coefficients $(P<0.001$; 
Table 4. Effect of straw particle size ${ }^{1}$ on the sorting $(\%)^{2}$ of dairy cows across the dry period and in the first $28 \mathrm{~d}$ of lactation $(\text { mean } \pm \mathrm{SE})^{3}$

\begin{tabular}{|c|c|c|c|c|c|}
\hline \multirow[b]{2}{*}{ Item } & \multicolumn{2}{|c|}{ Treatment $^{4}$} & \multicolumn{3}{|c|}{$P$-value } \\
\hline & Long dry diet & Short dry diet & Week & $\mathrm{T}^{5}$ & Week $\times \mathrm{T}$ \\
\hline \multicolumn{6}{|l|}{ Dry period } \\
\hline Long & $80.2 \pm 2.00 *$ & $88.4 \pm 1.96^{*}$ & 0.49 & 0.01 & 0.73 \\
\hline Medium & $103.4 \pm 0.61^{*}$ & $104.6 \pm 0.61^{*}$ & 0.02 & 0.19 & 0.46 \\
\hline Short & $106.2 \pm 0.39^{*}$ & $102.7 \pm 0.38^{*}$ & 0.68 & $<0.001$ & 0.85 \\
\hline Fine & $99.6 \pm 1.18$ & $90.71 \pm 1.16^{*}$ & 0.02 & $<0.001$ & 0.27 \\
\hline \multicolumn{6}{|l|}{ Lactating } \\
\hline Long & $99.6 \pm 1.16$ & $98.8 \pm 1.18$ & $<0.001$ & 0.66 & 0.48 \\
\hline Medium & $101.2 \pm 0.24^{*}$ & $101.3 \pm 0.24^{*}$ & 0.03 & 0.77 & 0.51 \\
\hline Short & $101.4 \pm 0.27^{*}$ & $101.3 \pm 0.27^{*}$ & 0.44 & 0.67 & 0.21 \\
\hline Fine & $96.1 \pm 0.68^{*}$ & $95.6 \pm 0.68^{*}$ & $<0.001$ & 0.62 & 0.77 \\
\hline
\end{tabular}

${ }^{1}$ Particle size determined by Penn State Particle Separator (Maulfair et al., 2011), which has a 19-mm screen (long), 8-mm screen (medium), 4-mm screen (short), and a pan (fine).

${ }^{2}$ Sorting $\%=$ actual DMI of each particle size fraction/predicted DMI of each particle size fraction $\times 100$. Sorting $\%=100$ means no sorting occurred, sorting $\%<100$ means sorting occurred against, and sorting $\%$ $>100$ means sorting occurred in favor.

${ }^{3}$ Long dry diet, $\mathrm{n}=20$ cows; short dry diet, $\mathrm{n}=20$ cows.

${ }^{4}$ Long dry diet: TMR with straw chopped with a 10.1-cm screen; short dry diet: TMR with straw chopped with a $2.54-\mathrm{cm}$ screen.

${ }^{5} \mathrm{~T}=$ treatment.

$* P<0.05=$ difference in sorting from $100 \%$.

Figure 4), with cows fed the LDD experiencing a more rapid daily decline in rumen $\mathrm{pH}$ in the week after calving compared with SDD cows.

During the lactating period, a week by treatment interaction was observed (Table 6; Figure 5), with cows fed the LDD treatment having higher BHB concentration compared with SDD treatment cows in the third week of lactation $(\mathrm{LDD}=1.3 \pm 0.11 ; \mathrm{SDD}=0.8 \pm$ $0.10 \mathrm{mmol} / \mathrm{L} ; P=0.005)$. Furthermore, cows fed the
LDD treatment tended to have a higher maximum BHB level compared with cows fed the SDD treatment (LDD $=1.6 \pm 0.16 \mathrm{mmol} / \mathrm{L} ; \mathrm{SDD}=1.2 \pm 0.16 \mathrm{mmol} / \mathrm{L} ; P$ $=0.08)$. No treatment effect was detected on glucose, calcium, NEFA, or haptoglobin during the lactating period (Table 6; Figure 2).

Milk production and efficiency of production did not differ by treatment (Table 7). A treatment by week interaction was observed for milk fat and protein con-

Table 5. Effect of straw particle size fed throughout the dry period on reticulorumen $\mathrm{pH}$ throughout the dry period and the first $28 \mathrm{~d}$ of lactation $(\text { mean } \pm \mathrm{SE})^{1}$

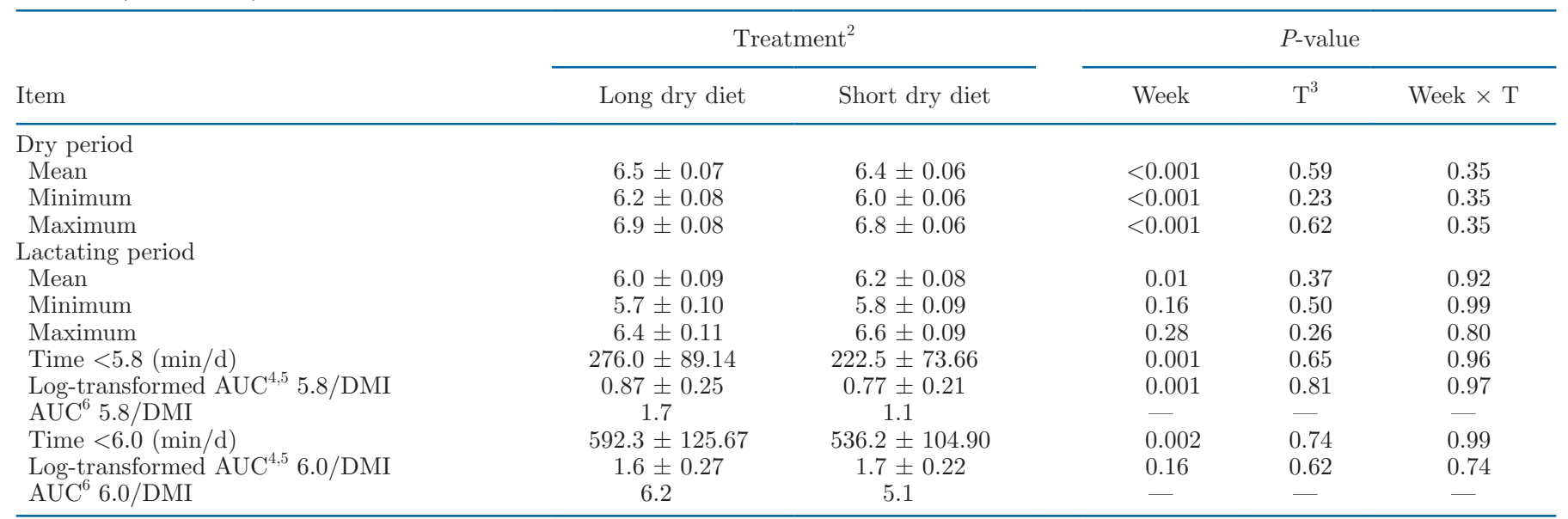

${ }^{1}$ Long dry diet; $\mathrm{n}=6$ cows; short dry diet, $\mathrm{n}=8$ cows.

${ }^{2}$ Long dry diet $=$ TMR with straw chopped with a 10.16-cm screen; short dry diet = TMR with straw chopped with a $2.54-\mathrm{cm}$ screen.

${ }^{3} \mathrm{~T}=$ treatment.

${ }^{4} \mathrm{AUC}=$ area under the curve. Data were normalized by taking the natural logarithm (value +1$)$ of these variables.

${ }^{5} \mathrm{AUC} / \mathrm{DMI}=$ area under the curve $\mathrm{pH}<5.8$ or $6.0(\mathrm{pH} \times \min / \mathrm{d})$ divided by DMI $(\mathrm{kg} / \mathrm{d})$.

${ }^{6}$ Back-transformed AUC data. 
tent, with cows fed the SDD treatment tending to have higher milk fat $(6.0 \pm 0.14 \%$ vs. $5.5 \pm 0.14 \%)$ and protein $(4.0 \pm 0.04 \%$ vs. $3.8 \pm 0.04 \%)$ during wk 1 of lactation compared with cows fed the LDD treatment. No treatment effect was observed on MUN or SCC (Table 7).

\section{DISCUSSION}

The objective of this study was to investigate the effect of the chop length of wheat straw in a high-straw dry cow diet on the feeding behavior, productivity, and physiology of cows across the transition period. In support of our hypothesis, the particle size of wheat straw affected feeding behavior during the dry period. Cows fed the SDD treatment had greater DMI than cows fed the LDD treatment during the dry period. Limited research has been focused on the effect of forage particle length in dry cow diets; however, in lactating diets, greater intake of a TMR containing shorter particles is consistent with Kononoff et al. (2003), where it was reported that cows fed corn silage with a shorter particle size consumed more DM compared with cows fed corn silage with a longer particle size. Other researchers (Yang and Beauchemin, 2007; Bhandari et al., 2008; Coon et al., 2018) have reported no differences in intake when reducing the chop length of either alfalfa hay or wheat straw in a lactating cow diet. In these previously mentioned studies, it was concluded that intake may have been compromised due to high NDF content of the diet. The NDF content of a ration is a major factor limiting DMI because of its contribution to gut fill. Specifically, if NDFI exceeds $1.1 \%$ of cow BW during the first 3 wk of lactation, their intake may be compromised (McCarthy et al., 2015a,b). There is no scientific recommendation for the level of NDF inclusion in the dry diet where intake becomes compromised, although in the present study, regardless of treatment, cows never exceeded $1.1 \%$ of their BW as NDFI.

During the dry period, feeding rate was affected by dietary treatment such that cows fed the SDD treatment tended to eat faster than cows fed the LDD treatment. This finding is consistent with Kononoff et al. (2003) who demonstrated that cows will consume their feed quicker when fed smaller forage particle sizes. Greter and DeVries (2011) further concluded that forage particle size likely influences feeding rate because cows may spend more time sorting through a ration with longer particles compared with smaller particles, thus slowing their rate of feed consumption. This is consistent with the present study such that cows fed the LDD sorted more than cows fed the SDD treatment; therefore, it is not surprising that LDD cows had a slower feeding rate than SDD cows. Cows fed the LDD treatment also consumed more meals/d than cows fed the SDD treatment. This finding is associated with the fact that cows fed the LDD treatment consumed less DM in a given meal compared with cows fed the SDD treatment. Cows fed the LDD treatment were likely limited in DMI within a given meal because the longer forage particle size would have filled the rumen more quickly than the shorter particle size, resulting in

Table 6. Effect of straw particle size fed throughout the dry period on blood parameters throughout the dry period and the first $28 \mathrm{~d}$ of lactation $(\text { mean } \pm \mathrm{SE})^{1}$

\begin{tabular}{|c|c|c|c|c|c|}
\hline \multirow[b]{2}{*}{ Item } & \multicolumn{2}{|c|}{ Treatment $^{2}$} & \multicolumn{3}{|c|}{$P$-value } \\
\hline & Long dry diet & Short dry diet & Week & $\mathrm{T}^{3}$ & Week $\times \mathrm{T}$ \\
\hline \multicolumn{6}{|l|}{ Dry period } \\
\hline Glucose $(\mathrm{mmol} / \mathrm{L})$ & $3.7 \pm 0.05$ & $3.7 \pm 0.05$ & 0.002 & 0.36 & 0.25 \\
\hline $\mathrm{BHB}(\mathrm{mmol} / \mathrm{L})$ & $0.4 \pm 0.02$ & $0.4 \pm 0.02$ & 0.20 & 0.24 & 0.55 \\
\hline $\mathrm{NEFA}^{4}(\mathrm{mmol} / \mathrm{L})$ & $0.1 \pm 0.03$ & $0.1 \pm 0.02$ & $<0.001$ & 0.78 & 0.20 \\
\hline Calcium $(\mathrm{mmol} / \mathrm{L})$ & $2.4 \pm 0.02$ & $2.4 \pm 0.02$ & 0.73 & 0.81 & 0.71 \\
\hline Natural-log-transformed haptoglobin (g/L) & $-1.5 \pm 0.08$ & $-1.4 \pm 0.08$ & $<0.001$ & 0.38 & 0.75 \\
\hline Haptoglobin $^{5}(\mathrm{~g} / \mathrm{L})$ & 0.3 & 0.4 & - & - & - \\
\hline \multicolumn{6}{|l|}{ Lactating period } \\
\hline Glucose $(\mathrm{mmol} / \mathrm{L})$ & $3.1 \pm 0.06$ & $3.1 \pm 0.05$ & 0.07 & 0.98 & 0.68 \\
\hline $\mathrm{BHB}(\mathrm{mmol} / \mathrm{L})$ & $0.9 \pm 0.06$ & $0.8 \pm 0.06$ & 0.003 & 0.10 & 0.05 \\
\hline NEFA (mmol/L) & $0.6 \pm 0.04$ & $0.5 \pm 0.04$ & $<0.001$ & 0.36 & 0.64 \\
\hline Calcium $(\mathrm{mmol} / \mathrm{L})$ & $2.4 \pm 0.02$ & $2.4 \pm 0.02$ & 0.001 & 0.55 & 0.91 \\
\hline Natural-log-transformed haptoglobin $(\mathrm{g} / \mathrm{L})$ & $-1.3 \pm 0.11$ & $-1.3 \pm 0.10$ & $<0.001$ & 0.91 & 0.69 \\
\hline Haptoglobin $^{5}(\mathrm{~g} / \mathrm{L})$ & 0.4 & 0.4 & - & - & - \\
\hline
\end{tabular}




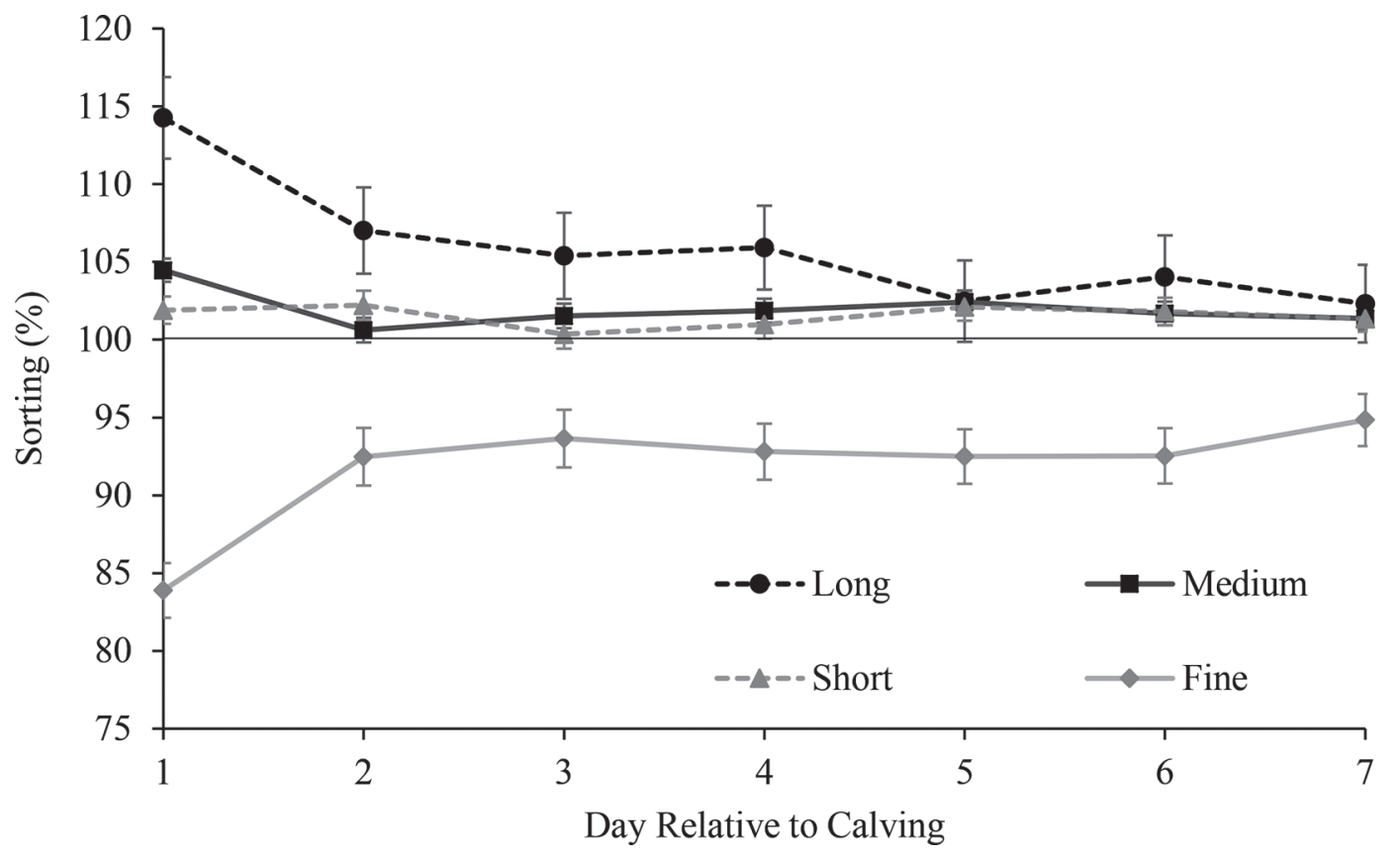

Figure 3. Sorting (\%; mean $\pm \mathrm{SE}$ ) for long (19-mm screen), medium (8-mm screen), short (4-mm screen), and fine (pan) particles for the first $7 \mathrm{~d}$ postpartum. Sorting $=[100 \times(\mathrm{DMI}$ of particle size $\mathrm{n}$ /predicted DMI of particle size $\mathrm{n})]$, where values equal to $100 \%$ indicate no sorting, $<100 \%$ indicate selective refusals (sorting against), and $>100 \%$ indicate preferential consumption (sorting for). Data are summarized across treatments for 40 cows.

the cows fed the LDD achieving rumen fill faster than cows fed the SDD (Allen, 1996). Longer forage particle size contributes to longer rumen retention time, as it takes more time for those long particles to be digested and move through the rumen (Jaster and Murphy, 1983). On the other hand, diets with smaller particle size would increase total digestibility, as those particles are degraded by microbes more efficiently than those of longer particle size (Heinrichs et al., 1999).

Cows fed the LDD treatment had a shorter interval between meals. This finding was not expected as the LDD diet was predicted to have a longer rumen retention time and, therefore, the long particles would be slower to pass through the rumen; thus, we would expect cows to be fuller for longer. Because cows fed the LDD sorted more against the long particles, it is possible that the diet they consumed was equally as digestible as the SDD. In that case, it could be hypothesized that because cows fed the LDD treatment were not consuming as much feed in a meal, they felt the onset of hunger more quickly than cows fed the SDD treatment. Despite differences in amount of feed consumed in a meal and time spent on a meal, straw particle size in the dry diet was not found to affect total meal time or total feeding time, which is consistent with the findings of Suarez-Mena et al. (2013). Alternatively, other researchers have demonstrated that increasing particle size increased time spent feeding within the day (Kononoff and Heinrichs, 2003; Kowsar et al., 2008; Alamouti et al., 2014). However, these researchers fed lactating dairy cows diets lower in forage concentration (40 to $57 \%$ of DM), whereas Suarez-Mena et al. (2013) used dry cows diets high in forage $(\sim 65 \%$ of $\mathrm{DM})$, similar to that of the current study.

Longer straw particle size in the dry cow diet did not affect rumination time, nor did it influence how much time cows spent ruminating per kilogram of DMI. Kayhani et al. (2013) reported similar results, suggesting that rumination time is not affected by increasing forage particle size. On the contrary, Beauchemin et al. (2003) found that reducing the particle size of alfalfa grass in lactating cow diets reduced time spent ruminating per kilogram of DMI. Beauchemin (2018) reported that rumination time is more correlated with NDFI rather than NDF content of the ration. Cows fed the SDD treatment ruminated less per unit of NDFI, which agrees with Kononoff and Heinrichs (2003); those researchers demonstrated that cows fed shorter chopped alfalfa hay spent less time ruminating per unit of NDF compared with cows fed long chopped alfalfa hay. In contrast, Suarez-Mena et al. (2013) reported no difference in rumination per unit of NDFI when cows were fed either short or long oat straw in dry cow diets; further, the rumination values that were reported were higher than those in the current study. Oat straw is less digestible than wheat straw (Drackley, 2005), thus it is 


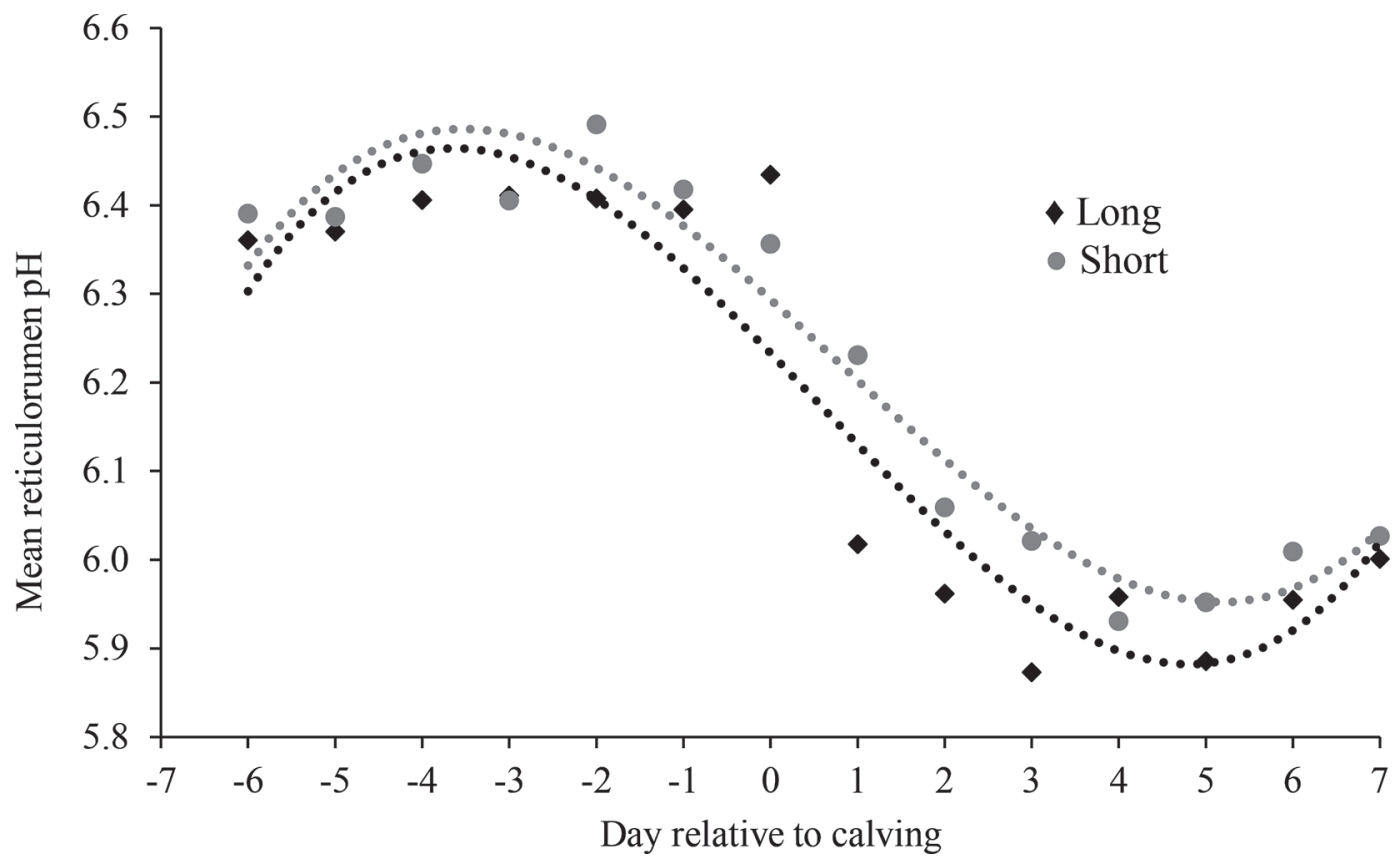

Figure 4. Mean daily reticulorumen $\mathrm{pH}$ for cows 1 wk precalving and 1 wk postcalving when fed dry cow diets differing in chop length of wheat straw: (1) chopped with a 2.54-cm screen [short dry diet (Short), $\mathrm{n}=8$ ] or (2) chopped with a 10.16-cm screen [long dry diet (Long), $\mathrm{n}$ $=6]$. Trend lines were constructed using analysis of covariance: $\mathrm{y}=-0.085 \mathrm{~d}-0.0011 \mathrm{~d}^{2}+0.0013 \mathrm{~d}^{3}+6.25\left(\mathrm{R}^{2}=0.95\right)$ for the short dry diet; $\mathrm{y}=-0.088 \mathrm{~d}-0.011 \mathrm{~d}^{2}+0.0013 \mathrm{~d}^{3}+6.19\left(\mathrm{R}^{2}=0.88\right)$ for the long dry diet.

possible that despite the shorter chop length, the cows required more time ruminating to further break down the straw. Less time spent ruminating per unit of NDFI would imply that the feed is processed quicker and can pass through the rumen more quickly, allowing cows to consume more feed (Nelson and Satter, 1992). Although greater NDF consumption for cows fed the SDD treatment is partially due to higher DMI, Kononoff et al. (2003) demonstrated that reducing particle size also resulted in less sorting and greater consumption of higher fiber particles, which is consistent with the findings of the present study. Last, greater consumption of more fibrous particles may explain why cows fed the SDD had greater DMI.

Regardless of treatment, cows sorted against the longest particles (mainly straw and corn silage stalks), but cows fed the LDD treatment sorted to a greater extent than cows fed the SDD treatment. This was expected as it has previously been demonstrated that lactating cows will sort against long fibrous fractions of the diet and in favor of the palatable grain component (MillerCushon and DeVries, 2017). Further, cows sort more when particle size is more easily distinguishable in the diet (Oelker et al., 2009), as was the case for the LDD treatment in the present study. Cows fed the LDD and the SDD treatment sorted similarly in favor of the medium particle fraction, which contained grain particles from the corn silage and supplement. Last, cows fed the LDD treatment did not sort for or against the fine fraction but cows fed the SDD treatment sorted against it. This is consistent with Coon et al. (2018), where it was shown that, when fed a lactating cow diet with $9 \%$ wheat straw differing in chop length, cows fed shorter chopped straw sorted against the fine fraction. On the contrary, Dancy et al. (2019) reported that when dry cows were fed a high-straw dry cow diet, they sorted in favor of the fine particles. A major difference between the 2 studies is that Dancy et al. (2019) fed a diet containing straw chopped with a 10.16 -cm screen, whereas the present study fed straw chopped with a $10.16-\mathrm{cm}$ screen (where no sorting occurred) and a 2.54-cm screen (where sorting occurred against fine particles); therefore, it is possible that the $2.54-\mathrm{cm}$ straw used in the present study and Coon et al. (2018) contributed mostly straw dust to the fine fraction and, therefore, cows sorted against these particles. Similarly, when offered finely chopped hay, calves sorted more against the fines compared with when they were offered coarsely chopped hay (Montoro et al., 2013). It was concluded that preference for forage components may depend on particle size (Montoro et al., 2013). Miller-Cushon and DeVries (2017) further concluded that a major factor contributing to feed sorting is palatability, with cows favoring sweet flavors. While lactating cows typically sort in favor of the short and fine particles, the main forage source in the present study was wheat straw, 
which cows may deem unpalatable; therefore, it may not be surprising that cows sorted against this fraction.

It is noteworthy that because of the high straw inclusion rate, the ration DM was quite high relative to other dry cow diets and, as such, sorting may have been enhanced across treatments. Past researchers have added water to lactating rations in attempt to bind the smaller particles to the larger particles with the goal of reducing sorting (Leonardi et al., 2005; Felton and DeVries, 2010; Fish and DeVries, 2012). To date, no research has been focused on how water addition may influence feed sorting in high-straw dry cow diets with relatively high DM, it would be hypothesized that water addition may further reduce sorting in high-straw dry cow diets. Sorting may have also been enhanced in the current study, across treatments, by the high refusal level (Miller-Cushon and DeVries, 2010). Further work, is thus needed, to determine if similar effects of straw particle size on sorting of dry cow diets would be observed at lower feeding levels.
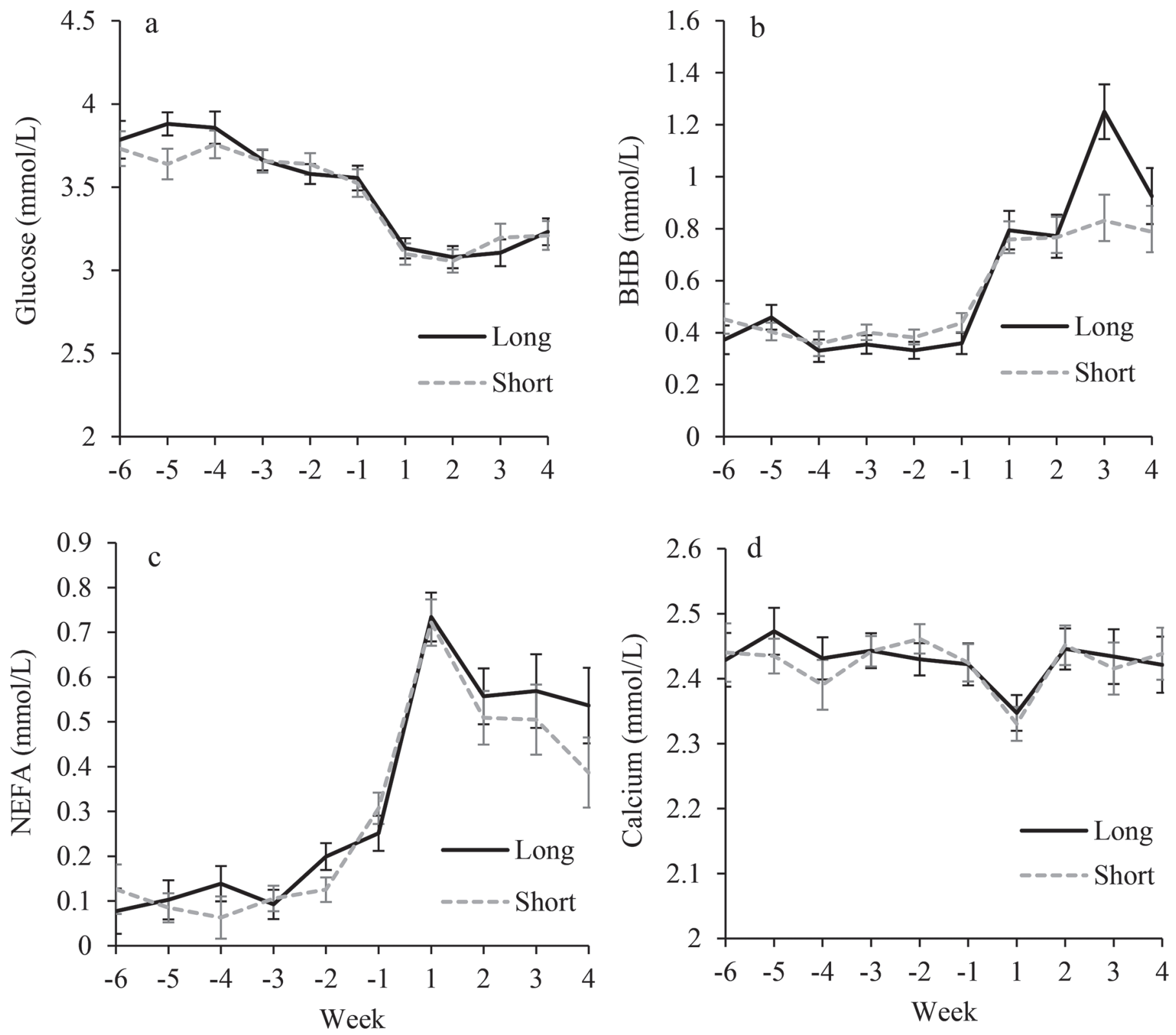

Figure 5. Average $( \pm \mathrm{SE})$ for (a) serum glucose (mmol/L), (b) whole-blood BHB (mmol/L), (c) serum nonesterified fatty acids (NEFA; $\mathrm{mmol} / \mathrm{L}$ ), and (d) serum calcium ( $\mathrm{mmol} / \mathrm{L}$ ) concentrations for cows fed 1 of 2 dietary treatments during the dry period that differed in chop length of wheat straw [long dry diet (Long) $=$ TMR with straw chopped with a 10.16-cm screen, $\mathrm{n}=20$; short dry diet (Short) $=$ TMR with straw chopped with a $2.54-\mathrm{cm}$ screen, $\mathrm{n}=20$ ]; upon calving, all cows were fed the same lactating cow ration. 
Researchers have demonstrated that dairy cattle may carry over a learned behavior as they transition through major life events (Miller-Cushon et al., 2013); as such, we hypothesized that if cows sorted their diet precalving, they would continue to sort in a similar manner postcalving. Contrary to this, cows did not differ in their sorting behavior postcalving, although, in the first week postcalving, cows on both treatments sorted in favor of the long particles and against the short and fine particles. To our knowledge, no research to date has investigated how cows alter their feed sorting behavior in the first week postcalving. The lactating diet is typically high in rapidly fermentable carbohydrates; thus, the shift from a high fiber to a high concentrate diet can alter the rumen environment (Penner et al., 2007). Cows sorting more in favor of the long fibrous particles and against the grain components is likely a behavioral result in response to the adaptation of the rumen to the new diet. This was also shown by DeVries et al. (2008) and Kmicikewycz and Heinrichs (2015), where cows altered their sorting behavior (sorting more in favor of the long particles and against the fine fractions) to attenuate the negative effects of SARA. In the current study, cows experienced a rapid drop in rumen $\mathrm{pH}$ as they transitioned to lactation (Figure 4), and during the first week postcalving, they spent more than $8 \mathrm{~h} / \mathrm{d}$ under a $\mathrm{pH}$ of 5.8 , confirming the experience of SARA. As a result, it is likely that to attenuate the effects of this drop in pH (DeVries et al., 2008, 2014a,b), cows sorted more in favor of the long particles and more against the rapidly fermentable grains.

Forage particle length and physically effective fiber play a large role in rumen health (Zebeli et al., 2012). The results from this study suggest that the shorter chopped straw did not negatively influence the rumen environment of cows during the dry period. This is not surprising as cows fed high straw diets are at low risk of experiencing SARA because of their relatively low DMI of a diet containing low levels of rapidly fermentable carbohydrates and the potential for straw to contribute to the rumen mat (Oetzel, 2007). Interestingly, cows fed the LDD treatment experienced a greater daily decline in rumen $\mathrm{pH}$ during the first week postcalving (Figure 4), suggesting that cows fed the SDD treatment had a more stable rumen as they transitioned onto the lactating cow TMR. This is likely the result of cows fed the SDD having more consistent DMI in the week leading up to calving, whereas cows fed the LDD experienced a more rapid drop in DMI during this time. Further, cows fed the SDD had larger meals in the dry period and this may have increased the adaptive capacity of the rumen. As cows typically increase their DMI linearly in the week following calving, meal size in the dry period may prime the rumen for larger meals postcalving.

No effect of dietary treatment on daily milk yield, ECM, or 4\% FCM was detected. Likewise, dietary

Table 7. Effect of straw particle size fed throughout the dry period on the milk production and composition of lactating dairy cows in the first $28 \mathrm{~d}$ of lactation $(\text { mean } \pm \mathrm{SE})^{1,2}$

\begin{tabular}{|c|c|c|c|c|c|c|c|}
\hline Item & \multicolumn{2}{|c|}{ Treatment $^{3}$} & \multicolumn{5}{|c|}{$P$-value } \\
\hline Milk & $39.7 \pm 0.88$ & $38.5 \pm 0.89$ & $<0.001$ & & 0.38 & 0.58 & \\
\hline $4 \% \mathrm{FCM}$ & $46.4 \pm 1.09$ & $46.3 \pm 1.09$ & $<0.001$ & & 0.93 & 0.16 & \\
\hline ECM & $48.6 \pm 1.14$ & $48.6 \pm 1.09$ & $<0.001$ & & 0.65 & 0.14 & \\
\hline \multicolumn{8}{|c|}{ Efficiency of milk production $(\mathrm{kg} / \mathrm{kg})$} \\
\hline ECM/DMI & $2.4 \pm 0.06$ & $2.4 \pm 0.06$ & $<0.001$ & & 0.93 & 0.69 & \\
\hline \multicolumn{8}{|l|}{ Milk composition (\%) } \\
\hline Fat & $5.1 \pm 0.11$ & $5.2 \pm 0.12$ & & $<0.001$ & 0.50 & & 0.06 \\
\hline Protein & $3.3 \pm 0.03$ & $3.3 \pm 0.03$ & & $<0.001$ & 0.31 & & 0.03 \\
\hline \multicolumn{8}{|l|}{ Milk component yield $(\mathrm{kg} / \mathrm{d})$} \\
\hline Fat & $2.1 \pm 0.07$ & $2.0 \pm 0.07$ & & 0.11 & 0.40 & & 0.11 \\
\hline Protein & $1.3 \pm 0.03$ & $1.3 \pm 0.03$ & & 0.10 & 0.28 & & 0.25 \\
\hline
\end{tabular}

${ }^{1}$ Long dry diet, $\mathrm{n}=20$ cows; short dry diet, $\mathrm{n}=20$ cows.

${ }^{2}$ Milk composition was tested on 2 consecutive days per week starting on d 5 for each cow, all values were averaged by cow, by week.

${ }^{3}$ Long dry diet $=$ TMR with straw chopped with a 10.16-cm screen; short dry diet = TMR with straw chopped with a 2.54 -cm screen.

${ }^{4} \mathrm{~T}=$ treatment.

${ }^{5}$ Somatic cell counts (cells/mL) were log-transformed, given that they did not meet the assumptions of normality.

${ }^{6}$ Back-transformed SCC data. 
treatment did not influence milk production efficiency. Milk production is highly correlated with DMI, so because there was no difference in DMI postcalving we would not expect to see a difference in milk yield.

Dietary treatment in the dry period had no effect on blood glucose, NEFA, calcium, BHB, or haptoglobin concentrations. This was expected as energy demands are relatively low and cows are at low risk of metabolic disease (Grummer, 1995). In the lactating period, cows fed the LDD tended to have a higher BHB level $3 \mathrm{wk}$ postpartum and tended to have a higher maximum BHB level, suggesting greater mobilization of body fat and subsequent ketogenesis. Given that cows were only tested and treated by farm staff from d 7 to 14 , the elevation in BHB in wk 3 for cows fed the LDD is very likely related to dietary treatment, and not related to farm ketosis treatments. This conclusion is further supported by cows fed the LDD having numerically higher NEFA levels. Postpartum NEFA and BHB levels are good indicators of the severity of NEB, as higher levels initiate more body fat mobilization (Ospina et al., 2013). Goldhawk et al. (2009) suggested that precalving feeding behavior is related to postcalving metabolic health, such that for every $1 \mathrm{~kg}$ drop in DMI in the week leading up to calving the risk of developing subclinical ketosis increased by $2.2 \times$ (Goldhawk et al., 2009). Likewise, Grummer et al. (2004) suggested a positive correlation between prepartum DMI and postpartum performance, specifically that reducing the drop in DMI in the weeks before calving can improve health in the weeks following calving. Cows fed the LDD treatment did experience a greater drop in intake in the week leading up to calving, which may explain why they tended to have higher BHB levels postcalving. This finding is in support of our hypothesis that cows fed shorter chopped straw had more consistent intake across the transition period and as a result, were at a lower risk of NEB after calving.

When accounting for BW, at 100 to $110 \%$ of their energy requirements, dry cows on the current trial required anywhere from 12 to $21 \mathrm{Mcal} / \mathrm{d}$ of $\mathrm{NE}_{\mathrm{L}}$ (NRC, 2001). While we aimed to target energy consumption to $19 \mathrm{Mcal} / \mathrm{d}$ of $\mathrm{NE}_{\mathrm{L}}$, the greater energy value of the TMR (1.51 Mcal $/ \mathrm{kg}$ of $\mathrm{NE}_{\mathrm{L}}$ ) relative to that formulated, coupled with greater intake than predicted, resulted in cows on both treatments over-consuming energy $\left(\mathrm{LDD}=22.7 \pm 0.53 \mathrm{Mcal} / \mathrm{d}\right.$ of $\mathrm{NE}_{\mathrm{L}} ; \mathrm{SDD}=$ $23.3 \pm 0.53 \mathrm{Mcal} / \mathrm{d}$ of $\mathrm{NE}_{\mathrm{L}}$ ). Despite accurate nutrition modeling, deviations between the formulated ration and what is actually prepared and fed to cows is inevitable (Turiello et al., 2017). In the present study, the over-consumption of energy, relative to requirements in the dry period, may have contributed to greater body fat mobilization than predicted after calving. As such, further work investigating particle size of more energy limiting dry-cow diets is warranted.

\section{CONCLUSIONS}

Cows fed a high-straw dry cow diet with a smaller straw particle size had improved intake during the dry period, sorted feed less, and maintained more consistent intake in the week leading up to calving. Measured markers of metabolism were not affected by dietary treatment during the dry period; however, during lactation, cows that were previously fed the dry diet with shorter chopped straw had more stable rumen $\mathrm{pH}$ in the first week postcalving and had lower blood BHB levels 3 wk postcalving. These results suggest that straw chopped to a smaller particle size (with a $2.54-\mathrm{cm}$ screen) in a high-straw dry cow diet had positive effects on intake and feeding behavior during the dry period, as well as on postpartum health.

\section{ACKNOWLEDGMENTS}

Thank you to the staff of the University of Guelph, Livestock Research and Innovation Centre-Dairy Facility (Elora, ON, Canada), and especially to Laura Wright for all her assistance and patience while facilitating this research project. Special thanks to Kaitlyn Dancy, Meagan King, Sarah Parsons, and Sydney Moore and of the University of Guelph (Guelph, ON, Canada) for their assistance with data collection. Thanks also to Bill Woodley (Woodley Dairy Direction, Stratford, ON, Canada) for his contributions to the conception of this project. This project was financially supported by a Natural Sciences and Engineering Research Council of Canada (Ottawa, ON, Canada) Collaborative Research and Development Grant with Trouw Nutrition (Guelph, ON, Canada), as well as from the Ontario Agri-Food Innovation Alliance Research Program of the University of Guelph and the Ontario Ministry of Agriculture, Food, and Rural Affairs (Guelph, ON, Canada). Further, project equipment was supported by contributions from the Canadian Foundation for Innovation (Ottawa, ON, Canada) and the Ontario Research Fund (Toronto, ON, Canada).

\section{REFERENCES}

Alamouti, A. A., M. Alikhani, G. R. Ghorbani, A. Teimouri-Yansari, and M. Bagheri. 2014. Response of early lactation Holstein cows to partial replacement of neutral detergent soluble fibre for starch in diets varying in forage particle size. Livest. Sci. 160:60-68. https:/ /doi.org/10.1016/j.livsci.2013.12.009.

Allen, M. S. 1996. Physical constraints on voluntary intake of forages by ruminants. J. Anim. Sci. 74:3063-3075. https://doi.org/10 $.2527 / 1996.74123063 x$. 
AOAC International. 2000. Official Methods of Analysis. Vol. I. 17th ed. AOAC International, Arlington, VA.

Beauchemin, K. A. 2018. Invited review: Current perspectives on eating and rumination activity in dairy cows. J. Dairy Sci. 101:47624784. https://doi.org/10.3168/jds.2017-13706.

Beauchemin, K. A., W. Z. Yang, and L. M. Rode. 2003. Effects of particle size of alfalfa-based dairy cow diets on chewing activity, ruminal fermentation and milk production. J. Dairy Sci. 86:630-643. https://doi.org/10.3168/jds.S0022-0302(03)73641-8.

Bhandari, S. K., S. Li, K. H. Ominski, K. M. Wittenberg, and J. C. Plaizier. 2008. Effects of the chop lengths of alfalfa silage and oat silage on feed intake, milk production, feeding behavior, and rumen fermentation of dairy cows. J. Dairy Sci. 91:1942-1958. https: //doi.org/10.3168/jds.2007-0358.

Canadian Council on Animal Care. 2009. Guidelines on: The Care and Use of Farm Animals in Research, Teaching and Testing. Canadian Council on Animal Care, Ottawa, ON, Canada.

Chapinal, N., D. M. Veira, D. M. Weary, and M. A. G. von Keyserlingk. 2007. Technical note: Validation of a system for monitoring individual feeding and drinking behavior and intake in group-housed cattle. J. Dairy Sci. 90:5732-5736. https://doi.org/ 10.3168/jds.2007-0331.

Coon, R. E., T. F. Duffield, and T. J. DeVries. 2018. Effect of straw particle size on the behavior, health, and production of early-lactation dairy cows. J. Dairy Sci. 101:6375-6387. https://doi.org/10 $.3168 /$ jds.2017-13920

Dancy, K. M., E. S. Riberio, and T. J. DeVries. 2019. Effect of dietary transition at dry off on the behaviour and physiology of dairy cows. J. Dairy Sci. 102:4387-4402. https://doi.org/10.3168/ jds.2018-15718.

DeVries, T. J., F. Dohme, and K. A. Beauchemin. 2008. Repeated ruminal acidosis challenges in lactating dairy cows at high and low risk for developing acidosis: Feed sorting. J. Dairy Sci. 91:39583967. https://doi.org/10.3168/jds.2008-1347.

DeVries, T. J., T. Schwaiger, K. A. Beauchemin, and G. B. Penner. 2014a. The duration of time that beef cattle are fed a high-grain diet affects feed sorting behavior both before and after acute ruminal acidosis. J. Anim. Sci. 92:1728-1737. https://doi.org/10.2527/ jas.2013-7252.

DeVries, T. J., T. Schwaiger, K. A. Beauchemin, and G. B. Penner. 2014b. Impact of severity of ruminal acidosis on feed sorting behaviour of beef cattle. Anim. Prod. Sci. 54:1238-1242. https://doi .org/10.1071/AN14227.

DeVries, T. J., M. A. G. von Keyserlingk, D. M. Weary, and K. A. Beauchemin. 2003. Measuring the feeding behavior of lactating dairy cows in early to peak lactation. J. Dairy Sci. 86:3354-3361. https://doi.org/10.3168/jds.S0022-0302(03)73938-1.

Dohme, F., T. J. DeVries, and K. A. Beauchemin. 2008. Repeated ruminal acidosis challenges in lactating dairy cows at high and low risk for developing acidosis: Ruminal pH. J. Dairy Sci. 91:35543567. https://doi.org/10.3168/jds.2008-1264.

Dohoo, I. R., and S. W. Martin. 1984. Sub-clinical ketosis: Prevalence and associations with production and disease. Can. J. Comp. Med. $48: 1-5$.

Drackley, J. 1999. Biology of dairy cows during the transition period: The final frontier? J. Dairy Sci. 82:2259-2273. https://doi.org/10 .3168/jds.S0022-0302(99)75474-3.

Drackley, J. 2005. New concepts in nutritional management of dry cows. Adv. Dairy Technol. 17:11-23.

Duffield, T. 2000. Subclinical ketosis in lactating dairy cows. Vet. Clin. North Am. Food Anim. Pract. 16:231-253.

Falk, M., A. Münger, and F. Dohme-Meier. 2016. Technical note: A comparison of reticular and ruminal $\mathrm{pH}$ monitored continuously with 2 measurement systems at different weeks of early lactation. J. Dairy Sci. 99:1951-1955. https://doi.org/10.3168/jds.2015-9725.

Felton, C. A., and T. J. DeVries. 2010. Effect of water addition to a total mixed ration on feed temperature, feed intake, sorting behavior, and milk production of dairy cows. J. Dairy Sci. 93:2651-2660. https://doi.org/10.3168/jds.2009-3009.

Fish, J. A., and T. J. DeVries. 2012. Varying dietary dry matter concentration through water addition: Effect on nutrient intake and sorting of dairy cows in late lactation. J. Dairy Sci. 95:850-855. https://doi.org/10.3168/jds.2011-4509.

Geishauser, T., K. Leslie, D. Kelton, and T. Duffield. 1998. Evaluation of five cowside tests for use with milk to detect subclinical ketosis in dairy cows. J. Dairy Sci. 81:438-443. https://doi.org/10.3168/ jds.S0022-0302(98)75595-X.

Goldhawk, C., N. Chapinal, D. M. Veira, D. M. Weary, and M. A. G. von Keyserlingk. 2009. Prepartum feeding behavior is an early indicator of subclinical ketosis. J. Dairy Sci. 92:4971-4977. https: /doi.org/10.3168/jds.2009-2242.

Greter, A., and T. J. DeVries. 2011. Effect of feeding amount on the feeding and sorting behaviour of lactating dairy cattle. Can. J. Anim. Sci. 91:47-54. https://doi.org/10.4141/CJAS10067.

Grummer, R. R. 1995. Impact of changes in organic nutrient metabolism on feeding the transition dairy cow. J. Anim. Sci. 73:28202833.

Grummer, R. R., D. G. Mashek, and A. Hayirli. 2004. Dry matter intake and energy balance in the transition period. Vet. Clin. North Am. Food Anim. Pract. 20:447-470. https://doi.org/10.1016/j .cvfa.2004.06.013.

Heinrichs, A. J., D. R. Buckmaster, and B. P. Lammers. 1999. Processing, mixing, and particle size reduction of forages for dairy cattle. J. Anim. Sci. 77:180-186.

Humer, E., K. Ghareeb, H. Harder, E. Mickdam, A. Khol-Parisini, and Q. Zebeli. 2015. Peripartal changes in reticuloruminal $\mathrm{pH}$ and temperature in dairy cows differing in the susceptibility to subacute rumen acidosis. J. Dairy Sci. 98:8788-8799. https://doi.org/ 10.3168/jds.2015-9893.

Janovick, N. A., Y. R. Biosclair, and J. K. Drackley. 2011. Prepartum dietary energy intake affects metabolism and health during the periparturient period in primiparous and multiparous Holstein cows. J. Dairy Sci. 94:1385-1400. https://doi.org/10.3168/jds.2010 -3303 .

Janovick, N. A., and J. K. Drackley. 2010. Prepartum dietary management of energy intake affects postpartum intake and lactation performance by primiparous and multiparous Holstein cows. J. Dairy Sci. 93:3086-3102. https://doi.org/10.3168/jds.2009-2656.

Jaster, E. H., and M. R. Murphy. 1983. Effects of varying forage particle size of forage on digestion and chewing behavior of dairy heifers. J. Dairy Sci. 66:802-810.

Kahyani, A., G. R. Ghorbani, M. Khorvash, S. M. Nasrollahi, and K. A. Beauchemin. 2013. Effects of alfalfa hay particle size in high concentrate diets supplemented with unsaturated fat: Chewing behavior, total tract digestibility and milk production of dairy cows. J. Dairy Sci. 96:7110-7119. https://doi.org/10.3168/jds .2012-6462.

Kanz, P., M. Drillich, D. Klein-Jöbstl, B. Mair, S. Borchardt, L. Meyer, I. Schwendenwein, and M. Iwersen. 2015. Suitability of capillary blood obtained by a minimally invasive lancet technique to detect subclinical ketosis in dairy cows by using 3 different electronic hand- held devices. J. Dairy Sci. 98:6108-6118. https://doi .org/10.3168/jds.2014-8957.

Kmicikewycz, A. D., and A. J. Heinrichs. 2015. Effect of corn silage particle size and supplemental hay on rumen $\mathrm{pH}$ and feed preference by dairy cows fed high-starch diets. J. Dairy Sci. 98:373-385. https://doi.org/10.3168/jds.2014-8103.

Kononoff, P. J., and A. J. Heinrichs. 2003. The effect of corn silage particle size and cottonseed hulls on cows in early lactation. J. Dairy Sci. 86:2438-2451. https://doi.org/10.3168/jds.S0022 -0302(03)73838-7.

Kononoff, P. J., A. J. Heinrichs, and H. A. Lehman. 2003. The effect of corn silage particle size on eating behaviour, chewing activities, and rumen fermentation in lactating dairy cows. J. Dairy Sci. 86:3343-3353

Kowsar, R., G. R. Ghorbani, M. Alikhani, M. Khorvash, and A. Nikkhah. 2008. Corn silage partially replacing short alfalfa hay to optimize forage use in total mixed rations for lactating cows. J. Dairy Sci. 91:4755-4764. https://doi.org/10.3168/jds.2008-1302.

Leonardi, C., and L. E. Armentano. 2003. Effect of quantity, quality, and length of alfalfa hay on selective consumption by dairy 
cows. J. Dairy Sci. 86:557-564. https://doi.org/10.3168/jds.S0022 -0302(03)73634-0.

Leonardi, C., F. Giannico, and L. E. Armentano. 2005. Effect of water addition on selective consumption (sorting) of dry diets by cattle. J. Dairy Sci. 88:1043-1049. https://doi.org/10.3168/jds.S0022 $-0302(05) 72772-7$.

MacDonald, P. D. M., and P. E. J. Green. 1988. User's guide to program MIX: An interactive program for fitting mixtures of distributions. Icathus Data Systems, Hamilton, Canada.

Maulfair, D. D., M. Fustini, and A. J. Heinrichs. 2011. Effect of varying total mixed ration particle size on rumen digesta and fecal particle size and digestibility in lactating dairy cows. J. Dairy Sci. 94:3527-3536. https://doi.org/10.3168/jds.2010-3718.

Maulfair, D. D., and A. J. Heinrichs. 2013. Effects of varying forage particle size and fermentable carbohydrates on feed sorting, ruminal fermentation, and milk and component yields of dairy cows. J. Dairy Sci. 96:3085-3097. https://doi.org/10.3168/jds.2012-6048.

McArt, J. A. A., D. V. Nydam, and G. R. Oetzel. 2012. Epidemiology of subclinical ketosis in early lactation dairy cattle. J. Dairy Sci. 95:5056-5066. https://doi.org/10.3168/jds.2012-5443.

McCarthy, M. M., T. Yasui, C. M. Ryan, S. H. Pelton, G. D. Mechor, and T. R. Overton. 2015a. Performance of early-lactation dairy cows as affected by dietary starch and monensin supplementation. J. Dairy Sci. 98:3335-3350. https://doi.org/10.3168/jds.2014 -8820 .

McCarthy, M. M., T. Yasui, C. M. Ryan, S. H. Pelton, G. D. Mechor, and T. R. Overton. 2015b. Metabolism of early-lactation dairy cows as affected by dietary starch and monensin supplementation. J. Dairy Sci. 98:3351-3365. https://doi.org/10.3168/jds.2014 -8821 .

Miller-Cushon, E. K., and T. J. DeVries. 2010. Feeding amount affects the sorting behavior of lactating dairy cows. Can. J. Anim. Sci. 90:1-7.

Miller-Cushon, E. K., and T. J. DeVries. 2017. Feed sorting in dairy cattle: Causes, consequences, and management. J. Dairy Sci. 100:4172-4183. https://doi.org/10.3168/jds.2016-11983.

Miller-Cushon, E. K., C. Montoro, A. Bach, and T. J. Devries. 2013. Effect of early exposure to mixed rations differing in forage particle size on feed sorting of dairy calves. J. Dairy Sci. 96:3257-3264. https://doi.org/10.3168/jds.2012-6415.

Montoro, C., E. K. Miller-Cushon, T. J. DeVries, and A. Bach. 2013. Effect of physical form of forage on performance, feeding behavior, and digestibility of Holstein calves. J. Dairy Sci. 96:1117-1124. https://doi.org/10.3168/jds.2012-5731.

Morris, T. R. 1999. Experimental Design and Analysis in Animal Sciences. CABI Publishing, New York, NY.

Nelson, W. F., and L. D. Satter. 1992. Impact of stage of maturity and method of preservation of alfalfa on digestion in lactating dairy cows. J. Dairy Sci. 75:1571-1580. https://doi.org/10.3168/ jds.S0022-0302(92)77914-4.

NRC. 2001. Nutrient Requirements of Dairy Cattle. 7th rev. ed. Natl. Acad. Press, Washington, DC.

Oelker, E. R., C. Reveneau, and J. L. Firkins. 2009. Interaction of molasses and monensin in alfalfa hay- or corn silage-based diets on rumen fermentation, total tract digestibility, and milk production by Holstein cows. J. Dairy Sci. 92:270-285. https://doi.org/ $10.3168 /$ jds.2008-1432.

Oetzel, R. 2007. Herd-level ketosis: Diagnosis and risk factors. Pages 67-91 in Proceedings of the 40th Conference of the American As- sociation of Bovine Practitioners, Vancouver, Canada. American Association of Bovine Practitioners, Ashland, $\mathrm{OH}$.

Ospina, P. A., J. McArt, T. Overton, T. Stokol, and D. V. Nydam. 2013. Using nonesterified fatty acids and $\beta$-hydroxybutyrate concentrations during the transition period for herd-level monitoring of increased risk of disease and decreased reproductive and milking performance. Vet. Clin. North Am. Food Anim. Pract. 29:387-412. https://doi.org/10.1016/j.cvfa.2013.04.003.

Penner, G. B., K. A. Beauchemin, and T. Mutsvangwa. 2007. Severity of ruminal acidosis in primiparous Holstein cows during the periparturient period. J. Dairy Sci. 90:365-375.

SAS Institute Inc. 2013. SAS version 9.4. SAS Institute Inc., Cary, NC.

Schirmann, K., M. A. G. von Keyserlingk, D. M. Weary, D. M. Veira, and W. Heuwieser. 2009. Technical note: Validation of a system for monitoring rumination in dairy cows. J. Dairy Sci. 92:6052-6055. https://doi.org/10.3168/jds.2009-2361.

Schwaiger, T., K. A. Beauchemin, and G. B. Penner. 2013. The duration of time that beef cattle are fed a high-grain diet affects the recovery from a bout of ruminal acidosis: Dry matter intake and rumen fermentation. J. Anim. Sci. 91:5729-5742. https://doi.org/ $10.2527 /$ jas.2013-6471.

Suarez-Mena, F. X., G. I. Zanton, and A. J. Heinrichs. 2013. Effect of forage particle length on rumen fermentation, sorting and chewing activity of late-lactation and non-lactating dairy cows. Animal 7:272-278. https://doi.org/10.1017/S1751731112001565.

Turiello, P., A. Larriestra, F. Bargo, A. Relling, and W. Weiss. 2017. Sources of variation in corn silage and total mixed rations of commercial dairy farms. Prof. Anim. Sci. 34:148-155. https://doi.org/ 10.15232 /pas.2017-01704.

Tyrrell, H. F., and J. T. Reid. 1965. Prediction of the energy value of cow's milk. J. Dairy Sci. 48:1215-1223. https://doi.org/10.3168/ jds.S0022-0302(65)88430-2.

Van Saun, R. J., and C. J. Sniffen. 2014. Transition cow nutrition and feeding management for disease prevention. Vet. Clin. North Am. Food Anim. Pract. 30:689-719. https://doi.org/10.1016/j.cvfa 2014.07.009.

Wildman, E. E., G. M. Jones, P. E. Wagner, R. L. Boman, H. F. Troutt, and T. N. Lesch. 1982. A dairy cow body condition scoring system and its relationship to selected production characteristics. J. Dairy Sci. 65:495-501. https://doi.org/10.3168/jds.S0022 -0302(82)82223-6.

Yang, W. Z., and K. A. Beauchemin. 2007. Altering physically effective fiber intake through forage proportion and particle length: Chewing and ruminal pH. J. Dairy Sci. 90:2826-2838. https://doi .org/10.3168/jds.2007-0032.

Zebeli, Q., J. R. Aschenbach, M. Tafaj, J. Boguhn, B. N. Ametaj, and W. Drochner. 2012. Invited review: Role of physically effective fiber and estimation of dietary fiber adequacy in high-producing dairy cattle. J. Dairy Sci. 95:1041-1056. https://doi.org/10.3168/ jds.2011-4421.

\section{ORCIDS}

T. F. Duffield (๑) https://orcid.org/0000-0001-6035-4669

A. J. Carpenter ๑ https://orcid.org/0000-0002-9779-0779

T. J. DeVries ๑ https://orcid.org/0000-0001-9364-2456 